\title{
Islet Autoantigens: Structure, Function, Localization, and Regulation
}

\author{
Peter Arvan ${ }^{1}$, Massimo Pietropaolo ${ }^{1}$, David Ostrov², and Christopher J. Rhodes ${ }^{3}$ \\ ${ }^{1}$ Division of Metabolism, Endocrinology \& Diabetes, University of Michigan Medical School, Ann Arbor, \\ Michigan 48105 \\ ${ }^{2}$ Department of Pathology, Immunology and Laboratory Medicine, University of Florida College of Medicine, \\ Gainesville, Florida 32610 \\ ${ }^{3}$ The Kovler Diabetes Center, Department of Medicine, University of Chicago, Chicago, Illinois 60637 \\ Correspondence: Parrvan@umich.edu
}

\begin{abstract}
Islet autoantigens associated with autoimmune type 1 diabetes (T1D) are expressed in pancreatic $\beta$ cells, although many show wider patterns of expression in the neuroendocrine system. Within pancreatic $\beta$ cells, every T1D autoantigen is in one way or another linked to the secretory pathway. Together, these autoantigens play diverse roles in glucose regulation, metabolism of biogenic amines, as well as the regulation, formation, and packaging of secretory granules. The mechanism(s) by which immune tolerance to islet-cell antigens is lost during the development of T1D, remains unclear. Antigenic peptide creation for immune presentation may potentially link to the secretory biology of $\beta$ cells in a number of ways, including proteasomal digestion of misfolded products, exocytosis and endocytosis of cellsurface products, or antigen release from dying $\beta$ cells during normal or pathological turnover. In this context, we evaluate the biochemical nature and immunogenicity of the major autoantigens in T1D including (pro)insulin, GAD65, ZnT8, IA2, and ICA69.
\end{abstract}

Plancis ncreatic $\beta$ cells are built for efficient regulated insulin secretion in response to acute changes in metabolic demand, which can exceed the rate at which new insulin can be synthesized. To accommodate this demand, $\beta$ cells presynthesize insulin secretory granules that are accumulated in the cytoplasm, commonly referred to as the insulin storage pool. Although overall pancreatic insulin content changes relatively little during acute secretory stimulation (Poitout et al. 2004), insulin content in $\beta$ cells responding to the secretory challenge acutely decreases, as detected by a decreased volume density of secretory granules (Stefan et al. 1987). Thereafter, up-regulated biosynthetic activity in the endoplasmic reticulum (ER) and Golgi complex of those cells (Stefan et al. 1987), orchestrated in conjunction with granule membrane protein recycling (Vo et al. 2004; Torii et al. 2005; Wasmeier et al. 2005) to form new granules (Orci et al. 1985) restores secretory granule abundance to its homeostatic set point (Trajkovski et al. 2008). The net result of this "insulin factory" (Orci 1985) is that the entire $\beta$-cell secretory pathway is tuned to be iteratively responsive to meals and other stimuli. This

Editors: Jeffrey A. Bluestone, Mark A. Atkinson, and Peter Arvan

Additional Perspectives on Type 1 Diabetes available at www.perspectivesinmedicine.org

Copyright (C) 2012 Cold Spring Harbor Laboratory Press; all rights reserved; doi: 10.1101/cshperspect.a007658

Cite this article as Cold Spring Harb Perspect Med 2012;2:a007658 
P. Arvan et al.

paradigm constitutes the basic secretory cell biology of the pancreatic $\beta$ cell, creating multiple opportunities for cell-surface exposure of many potential islet-cell autoantigens.

Type 1A diabetes (autoimmune T1D) results when autoreactive $\mathrm{T}$ cells become activated, resulting in destruction of insulin-secreting pancreatic $\beta$ cells. Even before the process of T1D is first recognized clinically, islet-cell autoantibody responses also become detectable (Atkinson and Maclaren 1993)_-indeed, onset of detectable islet autoantibodies can be used to predict the appearance of clinical T1D in otherwise healthy individuals (Orban et al. 2009). As the name indicates, immune autoreactivity is directed against self-antigens. Although we do not yet know if autoreactivity against endogenous $\beta$-cell protein antigens actually triggers onset of disease - this remains a leading hypothesis. The acknowledgment of autoantigens in pancreatic islet cells in patients with T1D (who may also have additional endocrinopathies) has been recognized for nearly 40 years-initially by immunofluorescence of human pancreas (Bottazzo et al. 1974) —and occasionally by cross-reaction in pancreatic $\beta$-cell lines in culture (in some cases even including $\beta$ cells of other species [Dotta and Eisenbarth 1989; Karounos and Thomas 1990]). The islet autoantigens identified to date tend to be largely (but not exclusively) proteinaceous.

Curiously, the majority of identified islet autoantigens are located within the secretory pathway of pancreatic $\beta$ cells. Indeed, most are located directly within the insulin secretory granule itself (the most abundant of these being insulin). It is not known why in T1D, secretory pathway proteins should be selected as antigens over proteins in other cellular compartments, or over other macromolecules such as RNAs or carbohydrates. However, the iterative surface exposure of T1D autoantigenic proteins, in conjunction with a susceptibility to autoimmunity in certain individuals, is a useful working hypothesis to explain these observations. One leading hypothesis for autoimmune susceptibility is a genetic predisposition to diminished thymic expression of islet-cell antigens, contributing to decreased self-tolerance. This could result in one or another secretory pathway protein serving as a "primary antigen" to which T-cell (as well as autoantibody) reactivity is directed at the earliest stage during a sequential progression of islet autoimmunity (Krishnamurthy et al. 2006). Alternatively, once autoimmunity in T1D is initiated, $\beta$-cell injury or activation may expose further antigens, increasing the number of targeted islet autoantigens-so-called epitope spreading (Pietropaolo et al. 2008). The sheer abundance of the major secretory pathway proteins of pancreatic $\beta$ cells makes them good candidates either as primary antigens or as secondary antigens involved in epitope spreading.

Using autoantibodies for immunoprecipitation, it has been possible to pursue the molecular identity of a number of major islet autoantigens - such an approach originally led to the identification of GAD65 (islet-cell antibodies to this antigen is now a standard clinical assay for the diagnosis of T1D), which encodes glutamic acid decarboxylase (Baekkeskov et al. 1990; Kaufman et al. 1992), an enzyme engaged in the synthesis of the neurotransmitter $\gamma$-aminobutyric acid (GABA, see below). In addition to GAD65, other major islet-cell autoantigens are now recognized, including proinsulin/insulin, ZnT8, IA2, and ICA69-in this work, we offer a brief perspective of each of these major $\beta$-cell autoantigens, their functions, and their exposure to the immune system at the time of initiation of T1D.

Because recent studies suggest that age at first presentation of clinical T1D is correlated with the mean levels of autoantibodies against insulin selectively (Steck et al. 2011), we consider this antigen first, and then proceed to review additional $\beta$-cell autoantigens.

\section{INSULIN}

Insulin is the central anabolic regulator of metabolic homeostasis, but for this discussion it is considered in its pathological role as a critical T1D autoantigen. Functional variation of the INS gene promoter conferred by the variable number of tandem repeats (VNTR) polymorphism, or mutations at other genetic loci, can lead to reduced insulin expression in the 
thymus and lymphoid organs that may lead to loss of tolerance to insulin (Vafiadis et al. 2001; Durinovic-Bello et al. 2005) (and other self-antigens [Nagamine et al. 1997; Anderson et al. 2002; Ramsey et al. 2002]). Immune responses to antigenic peptides within insulin and its precursor proteins are likely to drive the pathogenesis of T1D in at least some patients and animal models - and as noted above, insulin autoantibodies usually precede T1D onset and can (along with other autoantibodies) predict development of the disease (Gottlieb and Eisenbarth 2002). Further, in susceptible mice, T-cell clones (both CD4 and CD8) recognizing insulin, can transfer the disease (Daniel et al. 1995; Wong et al. 2009).

Insulin biosynthesis (see below) is estimated at $0.4 \%$ of total pancreatic protein synthesis (Permutt et al. 1984) despite that islets make up only $1 \%-2 \%$ of total pancreatic mass (Jansson 1994). The net result is that the INS gene product can represent up to $50 \%$ of the total production of $\beta$ cell protein under stimulated conditions (Eizirik et al. 2009). In $\beta$ cells, the initial site of insulin biosynthesis (and that of other insulin secretory granule proteins) is within the ER (Eskridge and Shields 1983) as preproinsulin, which includes the following contiguous peptides: a 24-residue signal peptide, the 30-residue $B$ chain, the 31-residue C-peptide plus two sets of two basic flanking amino acids, and the 21-residue A chain. Delivery of preproinsulin into the lumen of the ER is initiated by signal peptide binding to the signal recognition particle (Okun et al. 1990), followed by docking and translocation at the ER membrane (Eskridge and Shields 1983), and cleavage of the signal peptide (Dodson and Steiner 1998) associated with completion of proinsulin biosynthesis (Sando et al. 1972). Interestingly, the preproinsulin signal peptide is one of the sites containing epitopes to which "insulin autoantibodies” (Berg et al. 1993) and cytotoxic T lymphocytes (Skowera et al. 2008; Toma et al. 2009) can be directed.

Subsequently, in the secretory pathway, coordinated proteolytic cleavages excise the C peptide of proinsulin, dependent on the subtilisinlike convertases PC1 and PC2 (Smeekens et al. 1992; Furuta et al. 1997; Zhu et al. 2002) in con- junction with carboxypeptidase E (Naggert et al. 1995) to produce the mature two-chain hormone linked by two interchain disulfide bonds. The enzymic reactions converting proinsulin to insulin occur primarily within immature secretory granules beginning at the time of their emergence from the trans-Golgi network (Kuliawat and Arvan 1992; Huang and Arvan 1994).

It is back in the ER lumen where proinsulin folds into a globular protein that includes a nativelike insulin moiety and C-peptide, which lacks an ordered structure (Yang et al. 2010). Although the amino-terminal and carboxy-terminal parts of the $\mathrm{B}$ chain are flexible (Zoete et al. 2004), the central B-chain structure includes three notable features: (1) the interchain disulfide bonds that link $\mathrm{C}(\mathrm{B} 7)-\mathrm{C}(\mathrm{A} 7)$ and $\mathrm{C}(\mathrm{B} 19)-\mathrm{C}(\mathrm{A} 20)$ as is conserved in multiple members of the insulin/IGF superfamily (Blundell et al. 1983); (2) a 10-residue $\alpha$ helix running from S(B9) to C(B19) (Kristensen et al. 1997); and (3) a $\beta$ turn between residues $G(B 20)$ and G(B23) (Nakagawa et al. 2006). These features are especially interesting because proinsulin dimerizes (Derewenda et al. 1989)—possibly within the ER (Huang and Arvan 1995)_-and the proinsulin dimerization interface precisely matches that for insulin dimers (Blundell et al. 1972). In these dimers, the side chains of residues $S(B 9)-G(B 23)$ from each monomer contribute more than half of the surface area at the interface between the monomers (Fig. 1), and thus they are ordinarily buried when the properly folded protein resides within secretory compartments of the $\beta$ cell. In contrast, on exocytosis (Gold and Grodsky 1984), insulin very rapidly dissociates to its component monomers ( $\mathrm{B}$ chain disulfide linked to A chain is still considered a monomer) at which time S(B9) $-\mathrm{G}(\mathrm{B} 23)$ side chains become exposed. Indeed, the ability to form dimers is well correlated with the ability to activate insulin receptors (Nakagawa et al. 2000), in which the side chains of residues $\mathrm{V}(\mathrm{B} 12)$ and $\mathrm{Y}$ (B16) (Huang et al. 2004) as well as G(B23) (Baker et al. 1988) play significant roles.

T1D in nonobese diabetic (NOD) mice and in humans may have important differences, but NOD mice serve as one of the best animal models available for studies of autoimmune 
P. Arvan et al.

A

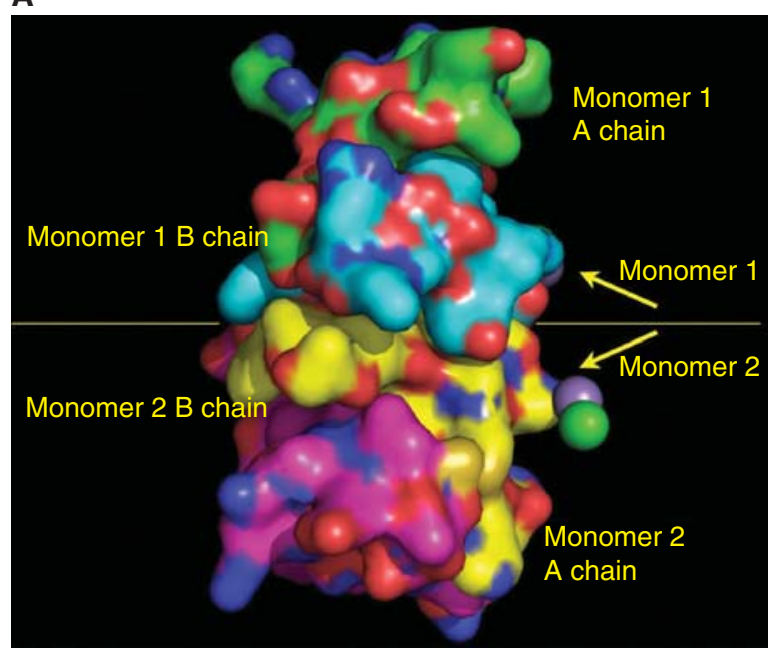

B

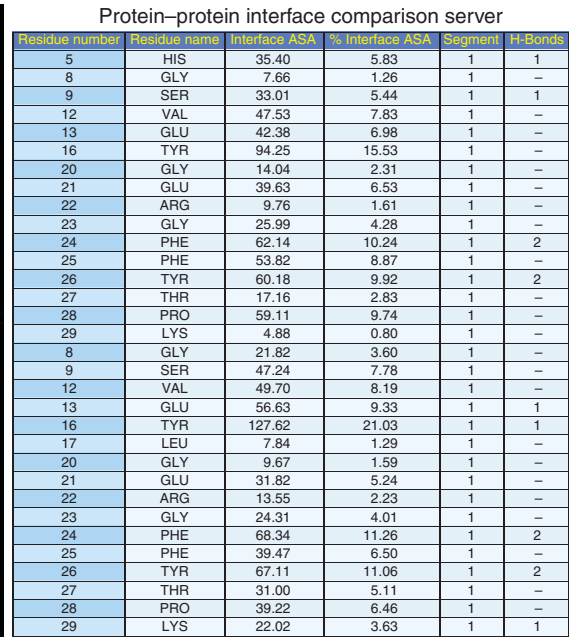

Figure 1. Insulin residues B9-B23 contribute to the dimerization interface between insulin monomers. $(A)$ The crystal structure (Protein Data Bank code 2R34) of two insulin monomers is displayed. Atoms underlying the molecular surface are colored blue for nitrogen, red for oxygen, and green for carbon for monomer $1 \mathrm{~A}$ chain, cyan for carbon for monomer $1 \mathrm{~B}$ chain, yellow for carbon for monomer $2 \mathrm{~B}$ chain, and magenta for carbon for monomer 2 A chain. A chloride ion is depicted as a green sphere. A manganese (II) ion is depicted as a purple sphere. $(B)$ The relative contribution of insulin B-chain residues from each monomer that contributes to the dimerization interface is shown. PROTORP was used to analyze the interfaces between insulin chains, which shows that B9-B23 residues participate in the dimerization interface. B16 tyrosine is buried at the interface contributing more (\% interface surface accessible area) to the dimerization interface $(21 \%)$ than other residues.

diabetes. Indeed, pathogenic $\mathrm{T}$ lymphocytes in NOD mice developing autoimmune diabetes recognize an immunodominant epitope contained within residues $S(B 9)-G(B 23)$ of pro(insulin), and this is also true in patients with recent-onset T1D (Alleva et al. 2001). In T1D patients with the HLA-DRB1*0401 (DR4) DQ8 haplotype (conferring susceptibility to T1D), another immunodominant epitope has been reported within proinsulin, which includes the carboxy-terminal portion of the C-peptide running through the endoproteolytic cleavage site contiguous with the A chain (Congia et al. 1998). Characterization of human T cells reacting to this cleavage-site autoantigen were found to be $\mathrm{CD}^{+}$FoxP3-positive (regulatory) T cells (Durinovic-Bello et al. 2006) rather than pathogenic T cells. Still other studies have found that in T1D patients with HLA DR4, either clonally expanded $\mathrm{T}$ cells from draining pancreatic lymph nodes, or insulin autoantibodies, recognize one or more epitopes within the insulin
A1-A15 sequence (Achenbach et al. 2004). However, in many recent-onset and long-standing T1D patients, peripheral blood monocytes produce IFN- $\gamma$ primarily in response to $\mathrm{B}$-chain (rather than A-chain) peptides (Toma et al. 2005). Indeed, in NOD mice, injection/immunization with recombinant Ins 2 A chain fails to protect from development of T1D, yet injection of the recombinant Ins2 B chain and, more narrowly, the B9-B23 peptide, does protect (Daniel et al. 1995; Muir et al. 1995). Curiously, with respect to subcutaneous "vaccination," injection of the B9-B23 from the Ins2 gene sequence [that begins with S(B9)] — but not the Ins1 B9B23 peptide [that begins with $\mathrm{P}(\mathrm{B} 9)$ ] - significantly protects NOD mice from diabetes (Devendra et al. 2004). Indeed the only difference between the B9-B23 peptide sequence from mouse Ins1 and Ins2 gene products is at the $\mathrm{B} 9$ position (Table 1) (moreover, the mouse Ins2 B9-B23 sequence is identical to that occurring in human insulin). 
Islet Autoantigens

Table 1. Peptide sequences of the B9-B23 peptide of human and mouse (pro)insulins

\begin{tabular}{llllllllllllllll}
\hline B chain & 9 & 10 & 11 & 12 & 13 & 14 & 15 & 16 & 17 & 18 & 19 & 20 & 21 & 22 & 23 \\
Mouse-Ins1 & P & H & L & V & E & A & L & Y & L & V & C & G & E & R & G \\
Mouse-Ins2 & S & H & L & V & E & A & L & Y & L & V & C & G & E & R & G \\
Human INS & S & H & L & V & E & A & L & Y & L & V & C & G & E & R & G \\
\hline
\end{tabular}

Curiously, a complete Ins2 knockout in the NOD background accelerates T1D onset (Thebault-Baumont et al. 2003); conversely, complete Ins1 knockout diminishes T1D onset (Moriyama et al. 2003). Complete knockout of both mouse Ins 1 and Ins 2 but carrying a human preproinsulin transgene bearing endogenous $\mathrm{S}$ (B9) and a $\mathrm{Y}(\mathrm{B} 16) \mathrm{A}$ point mutation provides sufficient insulin activity to avoid diabetes; more importantly, the animals do not develop T1D nor do they develop insulin autoantibodies (Nakayama et al. 2005). Altogether, the data seem to suggest that in NOD mice, specific structural features of the B chain are detected by the immune system with ( pro)insulin-I (bearing a proline residue at position B9) triggering pathogenic T-cell immune responses leading to diabetes. In contrast, in humans, if insulin B9B23 peptide serves as a primary autoantigen for $\mathrm{T} 1 \mathrm{D}$, then it must come from their one and only insulin gene product, which contains exclusively Ser at the B9 position.

\section{GAD65}

Early identification of L-glutamic acid decarboxylase (GAD) as a T1D autoantigen arose from immunoprecipitation studies (Baekkeskov et al. 1982) involving incubation of solubilized rat islets with sera from newly diagnosed T1D patients or controls, with the diabetic sera precipitating a $64-\mathrm{kDa}$ protein. Impressively, immunoreactivity to the $64-\mathrm{kDa}$ antigen was observed both in about $80 \%$ of new-onset T1D patients, and also in pre-T1D subjects. Thereafter, autoantibodies against the $64-\mathrm{kDa}$ antigen were found to react with pancreatic $\beta$ cells as well as GABAergic neurons in a rare condition termed stiff man syndrome (Solimena et al. 1988), facilitating subsequent identification of the 64-kDa autoantigen in T1D as GAD (Baekkeskov et al. 1990). Subsequent research on
GAD65 humoral autoimmunity in diabetes has led to the development of new assays to detect autoantibodies against GAD65, which are now used throughout the world (Grubin et al. 1994).

As noted above, GAD is the major enzyme required for production of the neurotransmitter, $\gamma$-amino butyric acid (GABA). GAD requires a cofactor, pyridoxal $5^{\prime}$-phosphate (i.e., activated vitamin B6) to catalyze this reaction. GAD and GABA are principally found in "GABA neurons" but are also found in extraneural tissues such as ovary and testis, and especially in pancreatic islet $\beta$ cells (Wang et al. 2007). Indeed in islets, GABA is stored in the synapticlike vesicles (SNLVs) of pancreatic $\beta$ cells (Sorenson et al. 1991), but the functional consequence of this is not yet entirely clear-although GABA has been proposed to have a local paracrine effect in islets in regulation of glucagon secretion (Wendt et al. 2004). However, the $\mathrm{GAD}^{-/-}$mouse does not show any particular islet dysfunction (Kash et al. 1999).

There are actually two isoforms of GAD which share $65 \%$ homology at the primary amino acid sequence level: GAD65 and GAD67 (Erlander et al. 1991). Intriguingly, GAD65 and GAD67 have identical enzymatic activities but have subtle differences in their structure, with GAD65 having more flexibility in the carboxyterminal region that is correlated with its far greater antigenicity (Fenalti and Buckle 2010). There is a well-documented body of data showing that early humoral autoimmune response to GAD65 in T1D is directed against epitopes primarily in the middle region of the molecule, and also includes the carboxyl terminus (Ronkainen et al. 2004, 2006). Additionally, intriguing structural crystallography studies aided by monoclonal antibody testing of antigenic determinants (Fenalti et al. 2008) have indicated that the more flexible carboxy-terminal region of GAD65 
P. Arvan et al.

shows a close grouping of autoantibody and $\mathrm{T}$ cell antigenic determinants, raising the possibility that antigen - antibody complexes could contribute to GAD65-induced T-cell reactivity. Although the importance of the middle region and the carboxyl terminus bearing major immunoreactive epitopes is recognized, epitope spreading to the amino-terminal region of GAD65 can occur later (Bonifacio et al. 2000; Schlosser et al. 2005) although not all studies have substantiated this (Novak et al. 2000; Hampe et al. 2002). The knowledge gained from our understanding of the development of immunoreactive autoantigenic epitopes has provided a useful tool to more accurately identify risk and prediction to insulin-requiring stages in susceptible populations-not only in "classic" T1D but also in more recently characterized forms of the disease such as latent autoimmune diabetes of adulthood (LADA) (Zimmet et al. 1994; Pietropaolo et al. 2007).

Unlike the case for deletion of the Ins1 gene, the cumulative incidence of autoimmune diabetes in NOD mice was reported to not be inhibited by GAD65 gene knockout (Yamamoto et al. 2004). However, autoimmune diabetes was inhibited by suppression of GAD expression in antisense-GAD transgenic/NOD females (Jun et al. 2002). Moreover, when splenocytes from female NOD $/ \mathrm{GAD}^{-1-}$ animals were transferred into female NOD-scid recipients, the onset of diabetes in the recipients was significantly delayed compared to recipients receiving splenocytes from ordinary NOD $/$ GAD $65^{+/+}$females (Kanazawa et al. 2009). Thus, although the data establish that GAD65 is not an obligate antigen for T1D in the NOD background, GAD65-reactive $\mathrm{T}$ cells do seem to contribute to T1D onset in this model.

Unlike the majority of islet-cell antigens, GAD65 (in SNLVs) and GAD67 (in cytosol) are localized away from the other islet-cell autoantigens in $\beta$ cells (Sorenson et al. 1991), i.e., not associated with dense-core insulin secretory granules (Fig. 2). Analogous to neuronal cells, both GAD65 and GAD67 are initially synthesized in the $\beta$-cell cytosol rather than the ER, and are subject to different acute translational regulation than proinsulin or other insulin se- cretory granule autoantigens (Uchizono et al. 2007; Wicksteed et al. 2007). However, like for proinsulin, it has been reported that longerterm exposure to glucose $(6-96 \mathrm{~h})$ in isolated islets can specifically increase the transcription of GAD65 above that of total protein synthesis (Björk et al. 1992; Hagopian et al. 1993).

It has been postulated that GAD65 undergoes a two-step posttranslational palmitoylation on two cysteine residues in the amino-terminal region required for SNLV targeting (Christgau et al. 1992), whereas GAD67 remains persistently cytosolic. The palmitoylated GAD65 is inserted into SNLV membranes, leaving the vast majority of SNLV-associated GAD65 outwardly facing the cytosol. At this location GAD65 associates with a small protein complex that contains the vesicular GABA transporter (VGAT). This allows local production of GABA by GAD65 and then GABA's immediate transport by VGAT into the SNLV storage compartment in the $\beta$ cell (Buddhala et al. 2009). GAD65 can be released from the membrane by an apparent enzyme activity in islets, suggesting that its membrane anchoring is potentially regulated. Unlike GAD67, the hydrophobic modifications and consequent membrane anchoring of GAD65 to GABA-containing SNLVs might be significant for its role as an islet autoantigen.

It is worth mentioning that human vascular endothelial cells (ECs) are capable of processing and presenting GAD65 epitopes to autoreactive $\mathrm{T}$ cells (Greening et al. 2003). In particular, in vitro transmigration across an EC monolayer by autoreactive $\mathrm{T}$ cells is markedly promoted by presentation of cognate peptide/HLA complexes on the EC surface, and is LFA-1 (lymphocyte function-associated antigen-1) dependent. These results suggest that presentation of autoantigens such as GAD 65 by islet endothelium in vivo could promote islet transmigration of circulating autoantigen-specific $\mathrm{T}$ cells primed in regional lymph nodes.

\section{ZNT8}

$\beta$ cells maintain an unusually high level of cellular zinc (Wijesekara et al. 2009), and they express several zinc transporters including ZnT5 


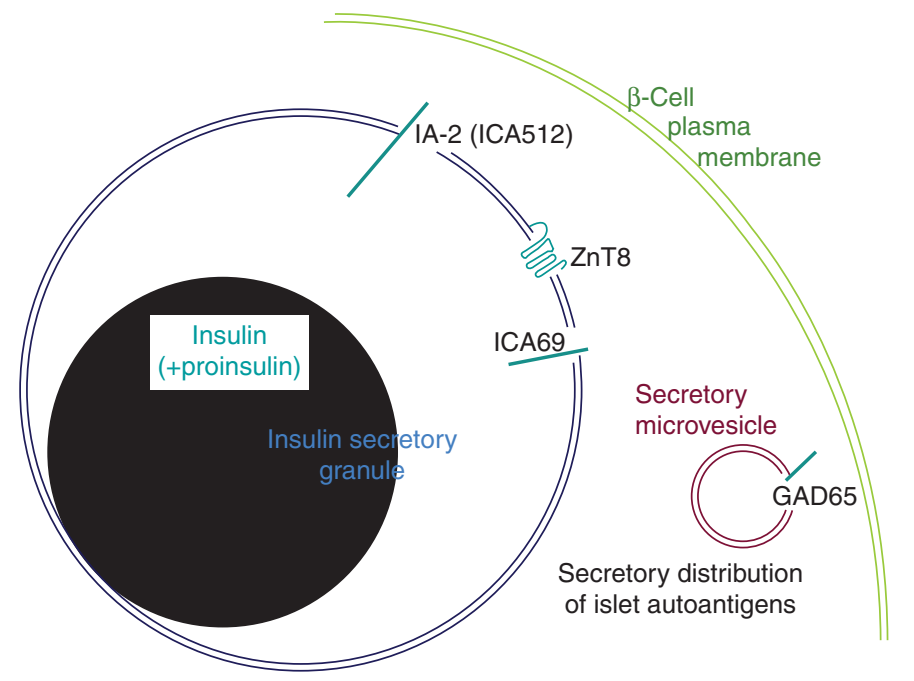

Figure 2. Predominant intracellular distribution of major T1D autoantigens in pancreatic $\beta$ cells. Two organelles of the $\beta$-cell secretory pathway are shown bearing autoantigens (in blue-green). The secretory granule contains primarily insulin (shown in black, similar to the appearance of the insulin crystal by transmission electron microscopy). A small fraction of unconverted proinsulin is also contained within secretory granules. The "clear space" surrounding the insulin granule core is thought to be enriched in the soluble C-peptide, which is not specifically denoted in the figure. The secretory granule membrane is the primary site of distribution of three additional $\beta$-cell autoantigens: ZnT8 is a polytopic membrane protein, IA-2 is a single-spanning transmembrane protein with both extensive luminal and cytosolic domains, and ICA69 is a type 1 transmembrane protein predominantly residing on the lumenal side of the membrane. As noted in the text, GAD65 localizes away from these other autoantigens, residing primarily on the cytosolic side of the membrane of secretory microvesicles, also known as "synaptic-like vesicles" (SNLVs).

(Kambe et al. 2002) and ZnT3 (Clifford and MacDonald 2000). However, the most consistently expressed $\beta$-cell zinc transporter is ZnT8 (encoded by SLC30A8), a 369 amino acid polytopic, dimeric membrane protein whose pancreatic expression is concentrated in the islets (Chimienti et al. 2004; Murgia et al. 2009). In $\beta$ cells (Chimienti et al. 2005), ZnT8 resides primarily in insulin secretory granules (Fig. 2) (Chimienti et al. 2006). ZnT8 has been found as an autoantigen in a high fraction of new-onset T1D patients (Wenzlau et al. 2007). Analysis of single-nucleotide polymorphisms has suggested that SLC30A8 polymorphisms are associated with type 2 diabetes in Scandinavians (Hertel et al. 2008), other Europeans, and East Asians (Cauchi et al. 2010)—but also associated with T1D (Wenzlau et al. 2008b). Autoantibodies againstZnT8 (Kawasaki et al. 2008, 2010; Achenbach et al. 2009; Lampasona et al. 2010; Nielsen et al. 2011) as well as T-cell responses (such as production of IFN- $\gamma$ ) against ZnT8 (Dang et al. 2010) are produced in patients that develop autoimmune diabetes. In turn, ZnT8 expression in $\beta$ cells is down-regulated by cytokines (Egefjord et al. 2009) even as this down-regulation could result in $\beta$-cell dysfunction (El Muayed et al. 2010) and apoptosis leading to further ZnT8 antigen exposure that could exacerbate autoimmunity (Wenzlau et al. 2008a).

Especially given the existence of several different zinc transporters in $\beta$ cells (Smidt et al. 2009), our understanding of the physiological role of ZnT8 in normal $\beta$-cell function is incomplete. However, substantial indirect evidence suggests that full ZnT8 function is needed for optimum insulin storage and secretion. Evidence suggests that TCF7L2 and PDX-1 (themselves both linked to normal versus pathological $\beta$-cell function) each contribute to regulation of 
P. Arvan et al.

ZnT8 expression (da Silva Xavier et al. 2009; Pound et al. 2010) and $d b / d b$ mice down-regulate $\beta$-cell ZnT8 protein (Tamaki et al. 2009). In the hopes of establishing a mechanistic link between ZnT8 expression and diabetes, multiple groups have examined ZnT8-deficient mice. Isolated islets of such mice have measurably decreased glucose-stimulated insulin secretion (Pound et al. 2009) and-with some variation between reports - a glucose intolerance phenotype that can be elicited on feeding the ZnT8deficient animals a diabetogenic diet (Lemaire et al. 2009; Nicolson et al. 2009). The phenotype is thought to be more obvious in animals with $\beta$-cell-selective deletion of ZnT8 (Wijesekara et al. 2010). Pancreatic $\beta$-cell lines with ZnT8 knockdown also show decreased glucose-stimulated insulin secretion ( $\mathrm{Fu}$ et al. 2009), and double knockdown of ZnT8 and ZnT3 reportedly triggers cell death in pancreatic $\beta$-cell lines (Petersen et al. 2011)_perhaps owing to cytosolic or nuclear zinc intoxication. Altogether, these studies indicate that down-regulation of ZnT8 expression can contribute to $\beta$-cell dysfunction and diminished survival, whereas its exposure as an autoantigen can trigger immune responses.

\section{IA-2 PHOSPHOTYROSINE PHOSPHATASE- RELATED PROTEINS}

Two other common autoantigens, IA2 (also known as ICA512) and IA2 $\beta$ (also known as phogrin) are also located to the insulin secretory granule membrane in $\beta$ cells (Solimena et al. 1996; Torii 2009). Autoantibodies against both proteins can be detected decades before overt diabetes in first-degree relatives of T1D probands, and their presence is used to identify subjects at risk of progressing to the clinical onset of the disease (Kawasaki et al. 1996; Morran et al. 2010). IA-2 consists of a signal peptide (a.a. 1-24), extracellular (a.a. 25-576), transmembrane (a.a. 577-600), and intracellular (a.a. 601-979) domains. Its proform is a glycoprotein of $110 \mathrm{kDa}$ that is processed by furin-like convertases during granule maturation (Mziaut et al. 2006). IA-2 is a granule membrane protein, whose cytosolic domain binds $\beta 2$-syntrophin, an F-actin-associated protein, and is cleaved on granule exocytosis. The resulting cleaved cytosolic fragment, ICA512-CCF, is thought to reach the nucleus and up-regulate the transcription of granule genes (including insulin and ICA512) and may also dimerize with intact ICA512 on granules to influence granule mobility in the cytoplasm (Trajkovski et al. 2008).

IA 2 and IA $2 \beta$ have domains with close homology to protein phosphotyrosine phosphatases (PTPs), yet surprisingly they do not have any such enzyme activity. IA2 and IA2 $\beta$ are both initially synthesized as proprotein precursors that are proteolytically processed likely by $\mathrm{PC} 1 / 3$ and/or PC2 in coordination with proinsulin. The mature IA 2 and IA $2 \beta$ proteins are type 1 integral membrane proteins, with the PTP domain oriented on the cytosolic side of the granule membrane and a short aminoterminal domain located on the inside of the granule. The actual function of IA2 and IA $2 \beta$ remains unknown, although in $\beta$ cells it has been postulated that they may play a role in regulating insulin secretory granule content and possibly regulation of $\beta$-cell growth (Torii 2009). In this regard the IA 2 and IA $2 \beta$ knockout mice are glucose intolerant with reduced insulin secretion (Saeki et al. 2002; Kubosaki et al. 2004). The double-knockout mouse has no worsening of this phenotype, although the insulin content of the islets is reduced by 50\% (Kubosaki et al. 2005). A recent report showed that deletion of IA- 2 and/or IA- $2 \beta$ results in a marked decrease in the number of dense-core vesicles (DCVs) in $\beta$ cells and a decrease in $\beta$ cell $\left[\mathrm{Ca}^{2+}\right]_{\mathrm{i}}$ handling (Cai et al. 2011). In the single IA-2 knockout (KO) mice, the decrease in the insulin content and secretion correlated with a decrease in $\beta$-cell DCV number. In the case of the double IA- 2 plus IA- $2 \beta$ KO mice, the decrease in $\beta$-cell DCV number was proportionally greater than the decrease in insulin content and secretion. Interestingly, electron microscopy of islets from $\mathrm{KO}$ mice revealed a marked increase in the number and size of lysosomes and an increase in LC3 protein, suggesting that autophagy might be involved in the consumption of DCVs. 
One might expect that secretion of insulin by granule exocytosis could increase the presentation of HLA class II allele-specific IA2 and IA2 $\beta$ native epitopes on the $\beta$-cell plasma membrane, where antigenicity could then be manifested. Naturally processed epitopes of islet-cell autoantigens represent the targets of effector and regulatory $\mathrm{T}$ cells in controlling $\beta$-cell-specific autoimmune responses (Di Lorenzo et al. 2007). In particular, naturally processed HLA class II allele-specific epitopes recognized by $\mathrm{CD}^{+}{ }^{+} \mathrm{T}$ cells, corresponding to the intracellular domain of IA2, were identified after native IA2 antigen was delivered to EpsteinBarr virus (EBV)-transformed B cells and peptides eluted and analyzed by mass spectrometry (Peakman et al. 1999). Dendritic cell subsets can facilitate the processing and presentation of soluble IA-2 antigen to $\mathrm{CD} 4^{+} \mathrm{T}$ cells. Specifically, at times near the onset of T1D, the plasmacytoid subset of dendritic cells is overrepresented in the blood, and these cells show a distinctive ability to capture islet autoantigenic immune complexes and enhance autoantigendriven $\mathrm{CD}^{+}{ }^{+} \mathrm{T}$-cell activation in the presence of IA-2 autoantibody-positive patient serum (Allen et al. 2009). This may suggest a synergistic proinflammatory role for plasmacytoid dendritic cells and IA-2 autoantibodies in T1D. The field is therefore heading toward the ultimate identification of novel naturally processed IA2 epitopes recognized by $\mathrm{CD} 4^{+} \mathrm{T}$ cells that may represent potential therapeutic agents, either in native form or as antagonistic altered peptide ligands, for the treatment of T1D.

\section{ICA69 AND OTHER T1D-RELATED AUTOANTIGENS}

Seminal studies by Atkinson et al. identified a subset of islet-cell antibodies (ICA) associated with a more clinically significant pancreatic $\beta$-cell injury in a subgroup of first-degree relatives of T1D probands. This subset of ICA was termed "non-GAD reactive" because ICA reactivity could only be partially blocked by GAD65 (Atkinson et al. 1993), implying that multiple additional islet autoantigens are recognized by T1D-specific humoral responses. We too found that a subset of cytoplasmic ICA is associated to a more rapid progression to insulin-requiring diabetes in GAD65 and IA2 antibody-positive relatives as compared to relatives with GAD65 and IA2 antibodies without ICA - again suggesting additional unidentified ICA-recognizing autoantigen(s) (Pietropaolo et al. 2005). This may reflect "epitope spreading," as solid observations indicate that islet autoantibody responses against multiple islet autoantigens are associated with progression to overt disease (Verge et al. 1996). With this in mind, a number of additional T1D-related autoantigens have been identified, which include islet cell autoantigen $69 \mathrm{kDa}$ (ICA69), the islet-specific glucose6-phosphatase catalytic subunit-related protein (IGRP), chromogranin A (ChgA) the insulin receptor, heat shock proteins, the antigens jun-B,16, CD38 (Pietropaolo and Eisenbarth 2001), peripherin, and glial fibrillary acidic protein (GFAP) (Winer et al. 2003; Haskins and Cooke 2011).

Islet-cell autoantigen 69 (ICA69), a protein product of human ICA1 or mouse Ical, is predominantly expressed in pancreatic islets and neuroendocrine organs (Pietropaolo et al. 1993; Karges et al. 1996). This protein and its Caenorhabditis elegans homolog ric-19 are conserved regulators of neuroendocrine secretion (Pilon et al. 2000; Sumakovic et al. 2009). ICA69 is involved in DCV signaling and maturation, and it is recruited to Golgi membranes by activated Rab2 (Buffa et al. 2008). ICA69 is thought to be a T1D autoantigen based on the following two observations. First, autoantibodies to ICA69 can be detected in both first-degree relatives of T1D patients who are followed to overt diabetes and in newly diagnosed diabetic patients (Pietropaolo et al. 1993; Martin et al. 1995; Roep et al. 1996; Dosch et al. 1999; Song et al. 2003). Second, T cells autoreactive to ICA69 can be detected in newly diagnosed diabetic children and in NOD mice (Winer et al. 2000; Chen et al. 2001). We have recently found that polymorphisms within the NOD Ical core promoter determines AIRE-mediated down-regulation of ICA69 expression in medullary thymic epithelial cells, thus providing a novel mechanistic explanation for the loss of immunologic tolerance to this 
P. Arvan et al.

self-antigen in autoimmunity in the NOD mouse model (Bonner et al. 2012).

IGRP is a member of the G6Pase family that is specifically expressed in pancreatic $\beta$ cells, as an ER resident protein (Arden et al. 1999). This molecule is a target of a significant subset of islet-associated $\mathrm{CD} 8^{+}$T cells in NOD mice (Santamaria et al. 1995). These CD8 ${ }^{+}$T cells express an invariant $\alpha$ chain characterized by $\mathrm{V} \alpha 17-$ J $\alpha 42$ recombination (DiLorenzo et al. 1998) and undergo a process of avidity maturation during the progression of islet inflammation to overt diabetes. IGRP has been shown to be a target of autoreactive CD8 ${ }^{+} \mathrm{T}$ cells in human autoimmune diabetes (Mallone et al. 2007). Extrathymic Aire/IGRP-expressing cells (eTACs) may help reinforce immune tolerance by preventing the maturation of autoreactive $\mathrm{T}$ cells that escape thymic negative selection (Gardner et al. 2008).

Another component of insulin secretory granules, chromogranin A (ChgA), has been recently proposed as an autoantigen of T1D (Stadinski et al. 2010). ChgA is a member of the granin protein family and is found throughout neuroendocrine tissues including the adrenal medulla, central nervous system, and pancreas (Taupenot et al. 2003). ChgA may also be needed during the development of the endocrine pancreas, as evidenced by the fact that ChgA knockout mice $\left(\mathrm{ChgA}^{-}\right)$have fewer islets and insulin-producing $\beta$ cells (Porte 1991). Of autoantigenic significance, ChgA aids in the formation of secretory granules (Kim et al. 2001) and is processed to form smaller peptides (Taupenot et al. 2003). In regards to T1D in NOD mice, an antigen from $\beta$-cell secretory granules that activates the diabetic T-cell clone BDC-2.5 and two other clones was identified as ChgA (Stadinski et al. 2010). Stadinski et al. went on to identify a sequence in the carboxyterminal region of ChgA, encoding the peptide WE-14, which activated all three T-cell clones. The results indicated that ChgA can trigger a Tcell-mediated immune response in NOD mice and that its WE-14 peptide is the antigenic epitope. In contrast, the role of ChgA as an autoantigen in human autoimmune diabetes remains to be elucidated.
Thought-provoking findings led to the hypothesis that early autoimmunity in spontaneous T1D can also target nervous system tissue elements in the pancreas, raising the concept that pathogenetic immune responses in T1D may also be non- $\beta$-cell exclusive (Winer et al. 2003). One of these molecular targets appears to be peripherin (Boitard et al. 1992). Peripherin is expressed in multiple endocrine tissues, including nerve fibers surrounding islets of Langerhans in the pancreas, adrenal medulla, nerve fibers in interstitial tissue between thyroid follicles, and nerve fibers adjacent to ovarian follicles (Chamberlain et al. 2010). Serologic responses to peripherin have been found in autonomic fibers in the pancreas, thyroid, and ovary, supporting clinical observations suggesting that neuronal elements may be a molecular target for immune-mediated injury in multiple forms of endocrine autoimmunity, including T1D (Chamberlain et al. 2010). However, it remains to be established as to whether or not the presence of peripherin antibodies, along with serologic responses to other putative neuronal elements, are predictive for the development of small fiber neuropathy (autonomic and/or somatic) and for the progression to overt diabetes.

\section{PROTEIN MISFOLDING AS A CONTRIBUTOR TO AUTOANTIGENICITY}

In addition to the physiological events of exocytotic protein exposure at the cell surface, $\beta$ cells have additional opportunities for generating antigens from major islet secretory pathway proteins. Conceivably, the misfolding of proinsulin and other secretory pathway proteins, when linked to pathways of endoplasmic reticulumassociated degradation (ERAD) (McCracken and Brodsky 2003), results in proteasomal processing of these polypeptides that could increase major histocompatibility complex (MHC) class I loading with availability of autoantigenic peptides to antigen-presenting cells (Eizirik et al. 2008). Overexpression of class I molecules (HLA$\mathrm{A}, \mathrm{B}$, and C) in pancreatic islets at the time of nset of T1D has long been recognized, in association with pancreatic infiltration with cytotoxic 
$\mathrm{CD}^{+}{ }^{+} \mathrm{T}$ cells surrounding damaged islets (Bottazzo et al. 1985). Increased MHC class I-related gene expression may be stimulated by cytokines but also under states of protein misfolding and cell stress, because MICA and MICB (MHC class I-related) are both regulated by heat-shock promoter elements similar to those of HSP70 genes (Groh et al. 1996). Thus, $\beta$-cell stress can potentially contribute to increased proteasomally derived antigen presentation, both by increasing ERAD and also by increasing expression of MHC class I-related gene products (Fig. 3).

Proinsulin, like other members of the IGF superfamily (Hober et al. 1994, 1999; Guo et al. 2002), is a protein predisposed to mispair its

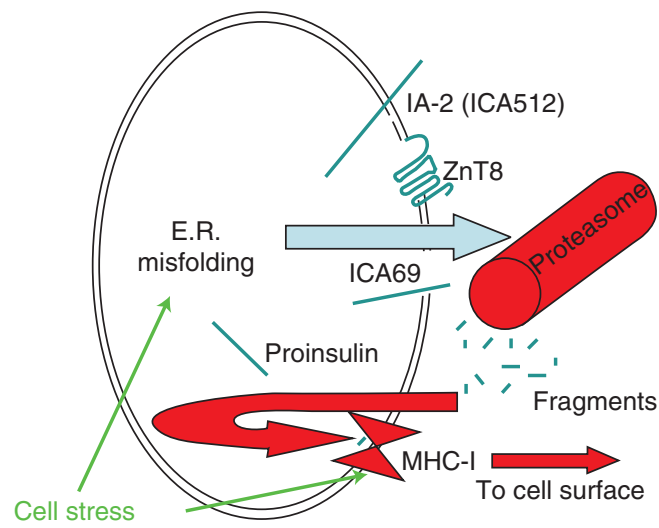

Hypothesis: ERAD pathway leading to antigen presentation

Figure 3. Hypothesis: ERAD of misfolded secretory pathway proteins triggers MHC class I loading and presentation of autoantigens. In the case of misfolded secretory pathway proteins, retrotranslocation from the ER to the cytosol triggers degradation via the ubiquitin-proteasome system. The generation of small cleavage fragments and their transport back into the ER lumen allows for peptide loading of MHC class I (via the TAP/tapasin complex). Cell stress can promote ER misfolding of secretory and membrane proteins (Kuznetsov and Nigam 1998) and also may promote expression of major histocompatibility complex class I-related genes (Groh et al. 1996). Thus, it is a plausible hypothesis that the net result of these two effects is enhanced $\beta$-cell autoantigen presentation. disulfide bonds during folding either in vivo (Liu et al. 2005) or in vitro (Hua et al. 1995, 2002; Qiao et al. 2003). Proinsulin misfolding becomes a virtual certainty in the syndrome of mutant INS gene-induced diabetes of youth (MIDY), in which heterozygotes bear one of 26 different mutations in the preproinsulin coding sequence linked to autosomal-dominant diabetes, that presents often (but not exclusively) in neonatal life (Liu et al. 2010b). These mutant proinsulins not only misfold within the ER, but they also block in trans the folding and maturation of proinsulin coexpressed from a wild-type allele (Hodish et al. 2010). Blockade of intracellular transport appears to be coupled-at least in part-to the proteasomal degradation of the misfolded mutant proinsulin as well as the coexpressed wild-type proinsulin (Liu et al. 2010a). Although patients with MIDY are not autoantibody positive, the idea that proinsulin misfolding leads to potential proteasomally generated proinsulin-derived peptides that could be antigens, is plausible. Interestingly, of the preproinsulin domains (signal peptide, B chain, C-peptide, and A chain) the majority of MIDY mutations fall within the B chain, including seven such mutations within the S(B9)G(B23) sequence. These data underscore the importance of this structurally sensitive region during the folding of proinsulin. This region is likely to remain structurally sensitive in mature insulin, because by X-ray crystallography, mature insulin monomers are likely to exist in two distinct states: the T state, in which the aminoterminal residues $\mathrm{F}(\mathrm{B} 1)-\mathrm{G}(\mathrm{B} 8)$ lead into a $\beta$ turn $[\mathrm{C}(\mathrm{B} 7)-\mathrm{H}(\mathrm{B} 10)]$ thereby "masking" the $\alpha$ helix beginning at residue $\mathrm{S}(\mathrm{B} 9)$; and the $\mathrm{R}$ state in which these same amino-terminal residues are in an extended conformation, thereby "exposing" the S(B9)-C(B19) $\alpha$ helix (Baker et al. 1988). Unanue and coworkers have suggested that in islet $\beta$ cells of NOD mice, the insulin B9-B23 peptide might be produced directly from processing of insulin derived from secretory granules (Mohan et al. 2010). Thus, there are multiple distinct changes in the conformational state of proinsulin and insulinmerely as one example-that may initiate its antigenicity. 
P. Arvan et al.

\section{REGULATION OF SECRETORY GRANULE AUTOANTIGEN PRODUCTION IN $\beta$ CELLS}

The biosynthesis of major secretory granule proteins is regulated by multiple nutrients, hormones, and neurotransmitters, the most notable of which is glucose (Rhodes 2004). Specifically, glucose coordinately regulates a subset of $\sim 50$ proteins in the $\beta$ cell-most destined for insulin secretory granules (Guest et al. 1989; Rhodes 2004) — such as proinsulin and its processing endopeptidases proPC1/3 and proPC2 (Alarcón et al. 1993; Martin et al. 1994). This increase in granule protein biosynthesis is initiated rapidly, i.e., up to 10 -fold within $60 \mathrm{~min}$ (Alarcón et al. 1993; Rhodes 2004), and this early response is controlled primarily at the translational level (Itoh and Okamoto 1980; Wicksteed et al. 2003). For prolonged periods of elevated glucose, there is a further effect on preproinsulin messenger RNA (mRNA) stability (Welsh et al. 1985) and increasing insulin gene transcription (Ohneda et al. 2000), which adds additional preproinsulin mRNA template potentially available for translation (Wicksteed et al. 2003). The mechanism for the specific glucose-induced increase in proinsulin translation is only partly understood, but it requires a highly conserved element in a $5^{\prime}$-untranslated region cis-element of the preproinsulin mRNA, called the preproinsulin glucose element (ppIGE) (Wicksteed et al. 2007). Interestingly, this ppIGE is also highly conserved in the $5^{\prime}$-untranslated region of the mRNA of other insulin secretory granule proteins whose biosynthesis is under the same specific glucose-induced translational control (Uchizono et al. 2007). In summary, the biosynthesis of insulin and selective other proteins is strongly and selectively up-regulated by glucose (Guest et al. 1991) so that protein constituents are coordinately regulated during secretory granule biogenesis.

In states of increased biosynthetic activity, proinsulin (and other protein) content in the ER increases (Eizirik et al. 2009), and under such conditions, the amount of misfolded proinsulin also increases (Liu et al. 2005). The ER stress response (also known as UPR) can initially protect $\beta$ cells by expanding ER capacity to meet the challenge of processing a physiological increase in proinsulin protein folding (Credle et al. 2005; Merksamer et al. 2008). However, in the face of sustained, high-level ER stress, chronic UPR activation may become cytotoxic when protective mechanisms in $\beta$ cells fail (Papa et al. 2003). Although pancreatic $\beta$-cell-reactive $\mathrm{T}$ cells may initiate $\beta$-cell destruction in T1D, stress response mechanisms (Akirav et al. 2008) in $\beta$ cells may actually accelerate the extent of disease progression. Specifically, not only can ER stress stimulate proteasomal generation of ERAD peptides (Fig. 3) but it may also directly promote $\beta$-cell death (Fig. 4). Indeed pancreatic $\beta$ cells are highly susceptible to ER stress-induced cytotoxicity (Ron and Walter 2007) with a potential direct contribution to several forms of human diabetes (Oslowski and Urano 2011). With respect to T1D, dendritic cell interaction with, and processing of, dead or damaged $\beta$ cells could lead to presentation of $\beta$-cell antigens to pathogenic T cells (Fig. 4) (Fonseca et al. 2009). However, autoimmune attack, by diminishing the $\beta$-cell population, may drive excessive translational activity in remaining $\beta$ cells as they are forced to synthesize larger and larger amounts of proinsulin/insulin [with increased proinsulin misfolding (Liu et al. 2005)], thereby elevating ER stress levels in the remaining $\beta$ cells (Todd et al. 2008). This in turn may promote further rounds of $\beta$-cell cytotoxicity while making additional antigen available for presentation to the immune system. Thus, both cytokine and secretory pathway stress could contribute to a vicious cycle in which secretory pathway antigens are connected to autoimmunity. For this reason, it is reasonable to postulate that cell compensatory responses might be critical modifiers of disease onset and activity, and might also be used as drug targets in T1D.

\section{CONCLUDING REMARKS}

There is still little understood about islet $\beta$-cell autoantigenicity. Are autoantigens the trigger of autoimmune attack, or collateral damage as part of an ongoing and premeditated immune destruction of a $\beta$ cell? The $\beta$-cell homicide versus suicide debate is still not resolved 


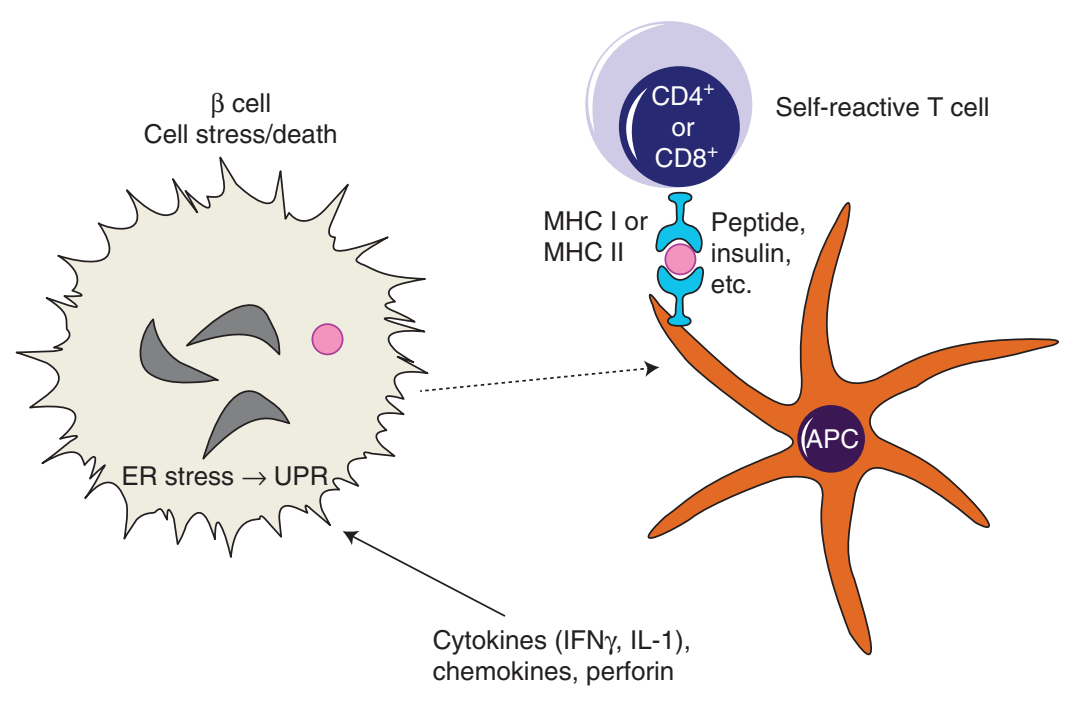

Hypothesis: $\beta$-cell damage leading to antigen presentation

Figure 4. Simplified model of $\beta$-cell damage leading to antigen presentation. T cells can directly kill $\beta$ cells through a cytotoxic process, but they can also influence $\beta$-cell destruction via release of mediators such as cytokines, chemokines, or perforin. Cytokine activation of inducible nitric oxide synthase can activate ER stress response signaling (Oyadomari et al. 2001)_pathways collectively known as the unfolded protein response (UPR). It is therefore conceivable that cell stress including UPR may be a potential contributor to $\beta$-cell toxicity in T1D. Processing of autoantigens within $\beta$ cells generates peptides that are then taken up by antigen-presenting cells (APCs), either as whole dead $\beta$ cells or $\beta$-cell fragments, for eventual further processing/presentation of these islet peptides to self-reactive T cells.

(Atkinson et al. 2011). But, with the possible exception of GAD65, it should be considered that the other major T1D autoantigens (pro)insulin, ZnT8, IA2, and IA2 $\beta$, are coordinately regulated at the biosynthetic level. When metabolic demand is increased there will be increased production of these antigenic proteins, which in turn increases the chances of their misfolding with production of antigenic peptides. Moreover, there will be increased insulin secretory granule exocytosis, which will result in a greater frequency of antigen presentation at the $\beta$-cell surface. So at least, during the pathogenesis of T1D, which includes increased excursions of hyperglycemia, there would be more active $\beta$ cells trying to produce and secrete more insulin to meet the demand, but this could also trigger $\beta$-cell demise. We conclude that in this particular situation, the $\beta$ cell, in conjunction with autoimmune attack, is undergoing an assisted suicide. However, this is mere conjecture, and what is really needed is cooper- ative research between immunologists and $\beta$ cell biologists to get at the root cause of T1D pathogenesis, and consequently to design new therapies that can help to avert the disease.

\section{ACKNOWLEDGMENTS}

We acknowledge the support of NIH R01 DK48280 (to P.A.), NIH R01 DK53456 and R01 DK56200 (to M.P), NIH 5U19AI05086409 (subcontract to D.O.), and NIH DK 50610 (to C.J.R.). We also acknowledge Bill and Dee Brehm and the Brehm Coalition for their efforts in discovery for type 1 diabetes.

\section{REFERENCES}

Achenbach P, Koczwara K, Knopff A, Naserke H, Ziegler AG, Bonifacio E. 2004. Mature high-affinity immune responses to (pro)insulin anticipate the autoimmune cascade that leads to type 1 diabetes. J Clin Invest 589-597.

Achenbach P, Lampasona V, Landherr U, Koczwara K, Krause S, Grallert H, Winkler C, Pfluger M, Illig T, 
P. Arvan et al.

Bonifacio E, et al. 2009. Autoantibodies to zinc transporter 8 and SLC30A8 genotype stratify type 1 diabetes risk. Diabetologia 52: 1881-1888.

Akirav E, Kushner JA, Herold KC. 2008. $\beta$-cell mass and type 1 diabetes: Going, going, gone? Diabetes 57: 28832888 .

Alarcón C, Lincoln B, Rhodes CJ. 1993. The biosynthesis of the subtilisin-related proprotein covertase PC3, but not that of the PC2 convertase, is regulated by glucose in parallel to proinsulin biosynthesis in rat pancreatic islets. J Biol Chem 268: 4276-4280.

Allen JS, Pang K, Skowera A, Ellis R, Rackham C, LozanoskaOchser B, Tree T, Leslie RD, Tremble JM, Dayan CM, et al. 2009. Plasmacytoid dendritic cells are proportionally expanded at diagnosis of type 1 diabetes and enhance islet autoantigen presentation to T-cells through immune complex capture. Diabetes 58: 138-145.

Alleva DG, Crowe PD, Jin L, Kwok WW, Ling N, Gottschalk M, Conlon PJ, Gottlieb PA, Putnam AL, Gaur A. 2001. A disease-associated cellular immune response in type 1 diabetics to an immunodominant epitope of insulin. $J$ Clin Invest 107: 173-180.

Anderson MS, Venanzi ES, Klein L, Chen Z, Berzins SP, Turley SJ, von Boehmer H, Bronson R, Dierich A, Benoist C, et al. 2002. Projection of an immunological self shadow within the thymus by the aire protein. Science 298 : 1395-1401.

Arden SD, Zahn T, Steegers S, Webb S, Bergman B, O'Brien RM, Hutton JC. 1999. Molecular cloning of a pancreatic islet-specific glucose-6-phosphatase catalytic subunit-related protein. Diabetes 48: 531-542.

Atkinson MA, Maclaren NK. 1993. Islet cell autoantigens in insulin-dependent diabetes. J Clin Invest 92: 1608-1616.

Atkinson MA, Kaufman DL, Newman D, Tobin AJ, Maclaren NK. 1993. Islet cell cytoplasmic autoantibody reactivity to glutamate decarboxylase in insulin-dependent diabetes. J Clin Invest 91: 350-356.

Atkinson MA, Bluestone JA, Eisenbarth GS, Hebrok M, Herold KC, Accili D, Pietropaolo M, Arvan PR, Von Herrath M, Markel DS, et al. 2011. How does type 1 diabetes develop?: The notion of homicide or $\beta$-cell suicide revisited. Diabetes 60: 1370-1379.

Baekkeskov S, Nielsen JH, Marner B, Bilde T, Ludvigsson J, Lernmark A. 1982. Autoantibodies in newly diagnosed diabetic children immunoprecipitate human pancreatic islet cell proteins. Nature 298: 167-169.

Baekkeskov S, Aanstoot HJ, Christgau S, Reetz A, Solimena M, Cascalho M, Folli F, Richter-Olesen H, De Camilli P. 1990. Identification of the $64 \mathrm{~K}$ autoantigen in insulindependent diabetes as the GABA-synthesizing enzyme glutamic acid decarboxylase. Nature 347: 151-156.

Baker EN, Blundell TL, Cutfield JF, Cutfield SM, Dodson EJ, Dodson GG, Hodgkin DMC, Hubbard RE, Isaacs NW, Reynolds CD, et al. 1988. The structure of $2 \mathrm{Zn}$ pig insulin crystals at 1.5 A resolution. Philos Trans R Soc Lond B Biol Sci 319: 369-456.

Berg H, Walter M, Mauch L, Seissler J, Northemann W. 1993. Recombinant human preproinsulin. Expression, purification and reaction with insulin autoantibodies in sera from patients with insulin-dependent diabetes mellitus. J Immunol Methods 164: 221-231.
Björk E, Kämpe O, Karlsson FA, Pipeleers DG, Andersson A, Hellerström C, Eizirik DL. 1992. Glucose regulation of the autoantigen GAD65 in human pancreatic islets. J Clin Endocrinol Metab 75: 1574-1576.

Blundell TL, Cutfield JF, Cutfield SM, Dodson EJ, Dodson GG, Hodgkin DC, Mercola DA. 1972. Three-dimensional atomic structure of insulin and its relationship to activity. Diabetes 21: 492-505.

Blundell TL, Bedarkar S, Humbel RE. 1983. Tertiary structures, receptor binding, and antigenicity of insulinlike growth factors. Fed Proc 42: 2592-2597.

Boitard C, Villa MC, Becourt C, Gia HP, Huc C, Sempe P, Portier MM, Bach JF. 1992. Peripherin: An islet antigen that is cross-reactive with nonobese diabetic mouse class II gene products. Proc Natl Acad Sci 89: 172-176.

Bonifacio E, Lampasona V, Bernasconi L, Ziegler AG. 2000. Maturation of the humoral autoimmune response to epitopes of GAD in preclinical childhood type 1 diabetes. Diabetes 49: 202-208.

Bonner SM, Pietropaolo SL, Fan Y, Chang Y, Sethupathy P, Morran MP, Beems M, Giannoukakis N, Trucco G, Palumbo MO, et al. 2012. Sequence variation in the promoter of the Ical gene, which encodes a protein implicated in type 1 diabetes, causes the transcription factor AIRE to increase its binding and downregulate expression. J Biol Chem doi: 10.1074/jbc.M111.319020.

Bottazzo GF, Florin-Christensen A, Doniach D. 1974. Isletcell antibodies in diabetes mellitus with autoimmune polyendocrine deficiencies. Lancet 2: 1279-1283.

Bottazzo GF, Dean BM, McNally JM, MacKay EH, Swift PG, Gamble DR. 1985. In situ characterization of autoimmune phenomena and expression of HLA molecules in the pancreas in diabetic insulitis. $N$ Engl J Med 313: $353-360$.

Buddhala C, Hsu CC, Wu JY. 2009. A novel mechanism for GABA synthesis and packaging into synaptic vesicles. Neurochem Int 55: 9-12.

Buffa L, Fuchs E, Pietropaolo M, Barr F, Solimena M. 2008. ICA69 is a novel Rab2 effector regulating ER-Golgi trafficking in insulinoma cells. Eur J Cell Biol 87: 197-209.

Cai T, Hirai H, Zhang G, Zhang M, Takahashi N, Kasai H, Satin LS, Leapman RD, Notkins AL. 2011. Deletion of Ia2 and/or Ia- $2 \beta$ in mice decreases insulin secretion by reducing the number of dense core vesicles. Diabetologia 54: $2347-2357$.

Cauchi S, Del Guerra S, Choquet H, D’Aleo V, Groves CJ, Lupi R, McCarthy MI, Froguel P, Marchetti P. 2010. Meta-analysis and functional effects of the SLC30A8 rs13266634 polymorphism on isolated human pancreatic islets. Mol Genet Metab 100: 77-82.

Chamberlain JL, Pittock SJ, Oprescu AM, Dege C, Apiwattanakul M, Kryzer TJ, Lennon VA. 2010. Peripherin-IgG association with neurologic and endocrine autoimmunity. J Autoimmun 34: 469-477.

Chen W, Bergerot I, Elliott JF, Harrison LC, Abiru N, Eisenbarth GS, Delovitch TL. 2001. Evidence that a peptide spanning the B-C junction of proinsulin is an early autoantigen epitope in the pathogenesis of type 1 diabetes. $J$ Immunol 167: 4926-4935.

Chimienti F, Devergnas S, Favier A, Seve M. 2004. Identification and cloning of a $\beta$-cell-specific zinc transporter, 
ZnT-8, localized into insulin secretory granules. Diabetes 53: $2330-2337$.

Chimienti F, Favier A, Seve M. 2005. ZnT-8, a pancreatic $\beta$ cell-specific zinc transporter. Biometals 18: 313-317.

Chimienti F, Devergnas S, Pattou F, Schuit F, Garcia-Cuenca R, Vandewalle B, Kerr-Conte J, Van Lommel L, Grunwald D, Favier A, et al. 2006. In vivo expression and functional characterization of the zinc transporter ZnT8 in glucoseinduced insulin secretion. J Cell Sci 119: 4199-4206.

Christgau S, Aanstoot HJ, Schierbeck H, Begley K, Tullin S, Hejnaes K, Baekkeskov S. 1992. Membrane anchoring of the autoantigen GAD65 to microvesicles in pancreatic $\beta$ cells by palmitoylation in the $\mathrm{NH} 2$-terminal domain. $J$ Cell Biol 118: 309-320.

Clifford KS, MacDonald MJ. 2000. Survey of mRNAs encoding zinc transporters and other metal complexing proteins in pancreatic islets of rats from birth to adulthood: Similar patterns in the Sprague-Dawley and Wistar BB strains. Diabetes Res Clin Pract 49: 77-85.

Congia M, Patel S, Cope AP, De Virgiliis S, Sonderstrup G. 1998. T cell epitopes of insulin defined in HLA-DR4 transgenic mice are derived from preproinsulin and proinsulin. Proc Natl Acad Sci 95: 3833-3838.

Credle JJ, Finer-Moore JS, Papa FR, Stroud RM, Walter P. 2005. On the mechanism of sensing unfolded protein in the endoplasmic reticulum. Proc Natl Acad Sci 102: 18773-18784.

Dang M, Rockell J, Wagner R, Wenzlau JM, Yu L, Hutton JC, Gottlieb PA, Davidson HW. 2010. Human type 1 diabetes is associated with $\mathrm{T}$ cell autoimmunity to zinc transporter 8. J Immunol 186: 6056-6063.

Daniel D, Gill RG, Schloot N, Wegmann D. 1995. Epitope specificity, cytokine production profile and diabetogenic activity of insulin-specific $\mathrm{T}$ cell clones isolated from NOD mice. Eur J Immunol 25: 1056-1062.

da Silva Xavier G, Loder MK, McDonald A, Tarasov AI, Carzaniga R, Kronenberger K, Barg S, Rutter GA. 2009. TCF7L2 regulates late events in insulin secretion from pancreatic islet $\beta$-cells. Diabetes 58: 894-905.

Derewenda U, Derewenda Z, Dodson GG, Hubbard RE, Korber F. 1989. Molecular structure of insulin: The insulin monomer and its assembly. Br Med Bull 45: 4-18.

Devendra D, Paronen J, Moriyama H, Miao D, Eisenbarth GS, Liu E. 2004. Differential immune response to B:9-23 insulin 1 and insulin 2 peptides in animal models of type 1 diabetes. J Autoimmun 23: 17-26.

DiLorenzo TP, Graser RT, Ono T, Christianson GJ, Chapman HD, Roopenian DC, Nathenson SG, Serreze DV. 1998. Major histocompatibility complex class I-restricted T cells are required for all but the end stages of diabetes development in nonobese diabetic mice and use a prevalent T cell receptor $\alpha$ chain gene rearrangement. Proc Natl Acad Sci 95: 12538-12543.

Di Lorenzo TP, Peakman M, Roep BO. 2007. Translational mini-review series on type 1 diabetes: Systematic analysis of $\mathrm{T}$ cell epitopes in autoimmune diabetes. Clin Exp Immunol 148: 1-16.

Dodson G, Steiner D. 1998. The role of assembly in insulin's biosynthesis. Curr Opin Struct Biol 8: 189-194.
Dosch H, Cheung RK, Karges W, Pietropaolo M, Becker DJ. 1999. Persistent T cell anergy in human type 1 diabetes. J Immunol 163: 6933-6940.

Dotta F, Eisenbarth GS. 1989. Type I diabetes mellitus: A predictable autoimmune disease with interindividual variation in the rate of $\beta$ cell destruction. Clin Immunol Immunopathol 50: S85-S95.

Durinovic-Bello I, Jelinek E, Schlosser M, Eiermann T, Boehm BO, Karges W, Marchand L, Polychronakos C. 2005. Class III alleles at the insulin VNTR polymorphism are associated with regulatory $\mathrm{T}$-cell responses to proinsulin epitopes in HLA-DR4, DQ8 individuals. Diabetes 54: S18-S24.

Durinovic-Bello I, Rosinger S, Olson JA, Congia M, Ahmad RC, Rickert M, Hampl J, Kalbacher H, Drijfhout JW, Mellins ED, et al. 2006. DRB1*0401-restricted human T cell clone specific for the major proinsulin73-90 epitope expresses a down-regulatory T helper 2 phenotype. Proc Natl Acad Sci 103: 11683-11688.

Egefjord L, Jensen JL, Bang-Berthelsen CH, Petersen AB, Smidt K, Schmitz O, Karlsen AE, Pociot F, Chimienti F, Rungby J, et al. 2009. Zinc transporter gene expression is regulated by pro-inflammatory cytokines: A potential role for zinc transporters in $\beta$-cell apoptosis? BMC Endocr Disord 9: 7.

Eizirik DL, Cardozo AK, Cnop M. 2008. The role for endoplasmic reticulum stress in diabetes mellitus. Endocr Rev 29: $42-61$.

Eizirik DL, Colli ML, Ortis F. 2009. The role of inflammation in insulitis and $\beta$-cell loss in type 1 diabetes. Nat Rev Endocrinol 5: 219-226.

El Muayed M, Billings LK, Raja MR, Zhang X, Park PJ, Newman MV, Kaufman DB, O'Halloran TV, Lowe WL Jr. 2010. Acute cytokine-mediated downregulation of the zinc transporter $\mathrm{ZnT}$ 8 alters pancreatic $\beta$-cell function. J Endocrinol 206: 159-169.

Erlander MG, Tillakaratne NJ, Feldblum S, Patel N, Tobin AJ. 1991. Two genes encode distinct glutamate decarboxylases. Neuron 7: 91-100.

Eskridge EM, Shields D. 1983. Cell-free processing and segregation of insulin precursors. J Biol Chem 258: $11487-$ 11491.

Fenalti G, Buckle AM. 2010. Structural biology of the GAD autoantigen. Autoimmun Rev 9: 148-152.

Fenalti G, Hampe CS, Arafat Y, Law RH, Banga JP, Mackay IR, Whisstock JC, Buckle AM, Rowley MJ. 2008. COOHterminal clustering of autoantibody and T-cell determinants on the structure of GAD65 provide insights into the molecular basis of autoreactivity. Diabetes 57: $1293-$ 1301.

Fonseca SG, Burcin M, Gromada J, Urano F. 2009. Endoplasmic reticulum stress in $\beta$-cells and development of diabetes. Curr Opin Pharmacol 9: 763-770.

Fu Y, Tian W, Pratt EB, Dirling LB, Shyng SL, Meshul CK, Cohen DM. 2009. Down-regulation of ZnT8 expression in INS- 1 rat pancreatic $\beta$ cells reduces insulin content and glucose-inducible insulin secretion. PLoS ONE 4: e5679.

Furuta M, Yano H, Zhou A, Rouillé Y, Holst JJ, Carroll R, Ravazzola M, Orci L, Furuta H, Steiner DF. 1997. Defective prohormone processing and altered pancreatic islet morphology in mice lacking active SPC2. Proc Natl Acad Sci 94: 6646-6651. 
P. Arvan et al.

Gardner JM, Devoss JJ, Friedman RS, Wong DJ, Tan YX, Zhou X, Johannes KP, Su MA, Chang HY, Krummel MF, et al. 2008. Deletional tolerance mediated by extrathymic Aire-expressing cells. Science 321: 843-847.

Gold G, Grodsky GM. 1984. Kinetic aspects of compartmental storage and secretion of insulin and zinc. Experientia 40: 1105-1114.

Gottlieb PA, Eisenbarth GS. 2002. Insulin-specific tolerance in diabetes. Clin Immunol 102: 2-11.

Greening JE, Tree TI, Kotowicz KT, van Halteren AG, Roep BO, Klein NJ, Peakman M. 2003. Processing and presentation of the islet autoantigen GAD by vascular endothelial cells promotes transmigration of autoreactive T-cells. Diabetes 52: 717-725.

Groh V, Bahram S, Bauer S, Herman A, Beauchamp M, Spies T. 1996. Cell stress-regulated human major histocompatibility complex class I gene expressed in gastrointestinal epithelium. Proc Natl Acad Sci 93: 12445-12450.

Grubin CE, Daniels T, Toivola B, Landin-Olsson M, Hagopian WA, Li L, Karlsen AE, Boel E, Michelsen B, Lernmark A. 1994. A novel radioligand binding assay to determine diagnostic accuracy of isoform-specific glutamic acid decarboxylase antibodies in childhood IDDM. Diabetologia 37: 344-350.

Guest PG, Rhodes CJ, Hutton JC. 1989. Regulation of the biosynthesis of insulin secretory granule proteins: Co-ordinate translational control is exerted on some but not all granule matrix constituents. Biochem J 257: 431-437.

Guest PC, Bailyes EM, Rutherford NG, Hutton JC. 1991. Insulin secretory granule biogenesis. Co-ordinate regulation of the biosynthesis of the majority of constituent proteins. Biochem J 274: 73-78.

Guo ZY, Shen L, Feng YM. 2002. The different folding behavior of insulin and insulin-like growth factor 1 is mainly controlled by their B-chain/domain. Biochemistry (Mosc) 41: 1556-1567.

Hagopian WA, Karlsen AE, Petersen JS, Teague J, Gervassi A, Fujimoto W, Lernmark A. 1993. Regulation of glutamic acid decarboxylase diabetes autoantigen expression in highly purified isolated islets from Macaca nemestrina. Endocrinology 132: 2674-2681.

Hampe CS, Hammerle LP, Bekris L, Ortqvist E, Persson B, Lernmark A. 2002. Stable GAD65 autoantibody epitope patterns in type 1 diabetes children five years after onset. $J$ Autoimmun 18: 49-53.

Haskins K, Cooke A. 2011. CD4 T cells and their antigens in the pathogenesis of autoimmune diabetes. Curr Opin Immunol 23: 739-745.

Hertel JK, Johansson S, Raeder H, Midthjell K, Lyssenko V, Groop L, Molven A, Njolstad PR. 2008. Genetic analysis of recently identified type 2 diabetes loci in 1,638 unselected patients with type 2 diabetes and 1,858 control participants from a Norwegian population-based cohort (the HUNT study). Diabetologia 51: 971-977.

Hober S, Hansson A, Uhlen M, Nilsson B. 1994. Folding of insulin-like growth factor I is thermodynamically controlled by insulin-like growth factor binding protein. $\mathrm{Bi}$ ochemistry (Mosc) 33: 6758-6761.

Hober S, Lundstrom Ljung J, Uhlen M, Nilsson B. 1999. Insulin-like growth factors I and II are unable to form and maintain their native disulfides under in vivo redox conditions. FEBS Lett 443: 271-276.

Hodish I, Liu M, Rajpal G, Larkin D, Holz RW, Adams A, Liu L, Arvan P. 2010. Misfolded proinsulin affects bystander proinsulin in neonatal diabetes. J Biol Chem 285: 685694.

Hua QX, Gozani SN, Chance RE, Hoffmann JA, Frank BH, Weiss MA. 1995. Structure of a protein in a kinetic trap. Nat Struct Biol 2: 129-138.

Hua QX, Jia W, Frank BH, Phillips NF, Weiss MA. 2002. A protein caught in a kinetic trap: Structures and stabilities of insulin disulfide isomers. Biochemistry (Mosc) 41: $14700-14715$.

Huang XF, Arvan P. 1994. Formation of the insulin-containing secretory granule core occurs within immature $\beta$ granules. J Biol Chem 269: 20838-20844.

Huang XF, Arvan P. 1995. Intracellular transport of proinsulin in pancreatic $\beta$-cells: Structural maturation probed by disulfide accessibility. J Biol Chem 270: 20417-20423.

Huang K, Xu B, Hu SQ, Chu YC, Hua QX, Qu Y, Li B, Wang S, Wang RY, Nakagawa SH, et al. 2004. How insulin binds: The B-chain $\alpha$-helix contacts the L1 $\beta$-helix of the insulin receptor. J Mol Biol 341: 529-550.

Itoh N, Okamoto H. 1980. Translational control of proinsulin synthesis by glucose. Nature 283: 100-102.

Jansson L. 1994. The regulation of pancreatic islet blood flow. Diabetes Metab Rev 10: 407-416.

Jun HS, Khil LY, Yoon JW. 2002. Role of glutamic acid decarboxylase in the pathogenesis of type 1 diabetes. Cell Mol Life Sci 59: 1892-1901.

Kambe T, Narita H, Yamaguchi-Iwai Y, Hirose J, Amano T, Sugiura N, Sasaki R, Mori K, Iwanaga T, Nagao M. 2002. Cloning and characterization of a novel mammalian zinc transporter, ZnT-5, abundantly expressed in pancreatic ß-cells. J Biol Chem 277: 19049-19055.

Kanazawa Y, Shimada A, Oikawa Y, Okubo Y, Tada A, Imai T, Miyazaki J, Itoh H. 2009. Induction of anti-whole GAD65 reactivity in vivo results in disease suppression in type 1 diabetes. J Autoimmun 32: 104-109.

Karges W, Pietropaolo M, Ackerley CA, Dosch HM. 1996. Gene expression of islet cell antigen p69 in human, mouse, and rat. Diabetes 45: 513-521.

Karounos DG, Thomas JW. 1990. Recognition of common islet antigen by autoantibodies from NOD mice and humans with IDDM. Diabetes 39: 1085-1090.

Kash SF, Condie BG, Baekkeskov S. 1999. Glutamate decarboxylase and GABA in pancreatic islets: Lessons from knock-out mice. Horm Metab Res 31: 340-344.

Kaufman DL, Erlander MG, Clare-Salzler M, Atkinson MA, Maclaren NK, Tobin AJ. 1992. Autoimmunity to two forms of glutamate decarboxylase in insulin-dependent diabetes mellitus. J Clin Invest 89: 283-292.

Kawasaki E, Eisenbarth GS, Wasmeier C, Hutton JC. 1996. Autoantibodies to protein tyrosine phosphatase-like proteins in type I diabetes. Overlapping specificities to phogrin and ICA512/IA-2. Diabetes 45: 1344-1349.

Kawasaki E, Uga M, Nakamura K, Kuriya G, Satoh T, Fujishima K, Ozaki M, Abiru N, Yamasaki H, Wenzlau JM, et al. 2008. Association between anti-ZnT8 autoantibody specificities and SLC30A8 Arg325Trp variant in Japanese 
Islet Autoantigens

patients with type 1 diabetes. Diabetologia 51: 22992302.

Kawasaki E, Nakamura K, Kuriya G, Satoh T, Kuwahara H, Kobayashi M, Abiru N, Yamasaki H, Eguchi K. 2010. Autoantibodies to insulin, insulinoma-associated antigen-2, and zinc transporter 8 improve the prediction of early insulin requirement in adult-onset autoimmune diabetes. J Clin Endocrinol Metab 95: 707-713.

Kim T, Tao-Cheng JH, Eiden LE, Loh Y.P. 2001. Chromogranin A, an "on/off" switch controlling dense-core secretory granule biogenesis. Cell 106: 499-509.

Krishnamurthy B, Dudek NL, McKenzie MD, Purcell AW, Brooks AG, Gellert S, Colman PG, Harrison LC, Lew AM, Thomas HE, et al. 2006. Responses against islet antigens in NOD mice are prevented by tolerance to proinsulin but not IGRP. J Clin Invest 116: 3258-3265.

Kristensen C, Kjeldsen T, Wiberg FC, Schaffer L, Hach M, Havelund S, Bass J, Steiner DF, Andersen AS. 1997. Alanine scanning mutagenesis of insulin. J Biol Chem 272: 12978-12983.

Kubosaki A, Gross S, Miura J, Saeki K, Zhu M, Nakamura S, Hendriks W, Notkins AL. 2004. Targeted disruption of the IA- $2 \beta$ gene causes glucose intolerance and impairs insulin secretion but does not prevent the development of diabetes in NOD mice. Diabetes 53: 1684-1691.

Kubosaki A, Nakamura S, Notkins AL. 2005. Dense core vesicle proteins IA-2 and IA-2 $\beta$ : Metabolic alterations in double knockout mice. Diabetes 54: S46-S51.

Kuliawat R, Arvan P. 1992. Protein targeting via the "constitutive-like" secretory pathway in isolated pancreatic islets: Passive sorting in the immature granule compartment. J Cell Biol 118: 521-529.

Kuznetsov G, Nigam SK. 1998. Folding of secretory and membrane proteins. N Engl J Med 339: 1688-1695.

Lampasona V, Petrone A, Tiberti C, Capizzi M, Spoletini M, di Pietro S, Songini M, Bonicchio S, Giorgino F, Bonifacio E, et al. 2010. Zinc transporter 8 antibodies complement GAD and IA-2 antibodies in the identification and characterization of adult-onset autoimmune diabetes: Non insulin requiring autoimmune diabetes (NIRAD) 4. Diabetes Care 33: 104-108.

Lemaire K, Ravier MA, Schraenen A, Creemers JW, Van de Plas R, Granvik M, Van Lommel L, Waelkens E, Chimienti F, Rutter GA, et al. 2009. Insulin crystallization depends on zinc transporter ZnT8 expression, but is not required for normal glucose homeostasis in mice. Proc Natl Acad Sci 106: 14872-14877.

Liu M, Li Y, Cavener D, Arvan P. 2005. Proinsulin disulfide maturation and misfolding in the endoplasmic reticulum. J Biol Chem 280: 13209-13212.

Liu M, Haataja L, Wright J, Wickramasinghe NP, Hua QX, Phillips NF, Barbetti F, Weiss MA, Arvan P. 2010a. Mutant INS-gene induced diabetes of youth: Proinsulin cysteine residues impose dominant-negative inhibition on wildtype proinsulin transport. PLOS ONE 5: e13333.

Liu M, Hodish I, Haataja L, Lara-Lemus AR, Rajpal G, Wright J, Arvan P. 2010b. Proinsulin misfolding and diabetes: Mutant INS gene-induced diabetes of youth Trends Endocrinol Metab 21: 652-659.

Mallone R, Martinuzzi E, Blancou P, Novelli G, Afonso G, Dolz M, Bruno G, Chaillous L, Chatenoud L, Bach JM, et al. 2007. $\mathrm{CD}^{+}$T-cell responses identify $\beta$-cell auto- immunity in human type 1 diabetes. Diabetes 56: 613-621.

Martin SK, Carroll R, Benig M, Steiner DF. 1994. Regulation by glucose of the biosynthesis of PC2, PC3 and proinsulin in $(\mathrm{ob} / \mathrm{ob})$ mouse islets of Langerhans. FEBS Lett 356: $279-282$.

Martin S, Kardorf J, Schulte B, Lampeter EF, Gries FA, Melchers I, Wagner R, Bertrams J, Roep BO, Pfutzner A. 1995. Autoantibodies to the islet antigen ICA69 occur in IDDM and in rheumatoid arthritis. Diabetologia 38: 351-355.

McCracken AA, Brodsky JL. 2003. Evolving questions and paradigm shifts in endoplasmic-reticulum-associated degradation (ERAD). Bioessays 25: 868-877.

Merksamer PI, Trusina A, Papa FR. 2008. Real-time redox measurements during endoplasmic reticulum stress reveal interlinked protein folding functions. Cell 135: 933-947.

Mohan JF, Levisetti MG, Calderon B, Herzog JW, Petzold SJ, Unanue ER. 2010. Unique autoreactive T cells recognize insulin peptides generated within the islets of Langerhans in autoimmune diabetes. Nat Immunol 11: 350-354.

Moriyama H, Abiru N, Paronen J, Sikora K, Liu E, Miao D, Devendra D, Beilke J, Gianani R, Gill RG, et al. 2003. Evidence for a primary islet autoantigen (preproinsulin 1) for insulitis and diabetes in the nonobese diabetic mouse. Proc Natl Acad Sci 100: 10376-10381.

Morran MP, Casu A, Arena VC, Pietropaolo S, Zhang YJ, Satin LS, Nelson P, Omenn GS, Trucco M, Becker DJ, et al. 2010. Humoral autoimmunity against the extracellular domain of the neuroendocrine autoantigen IA-2 heightens the risk of type 1 diabetes. Endocrinology 151: 2528 2537.

Muir A, Peck A, Clare-Salzler M, Song YH, Cornelius J, Luchetta R, Krischer J, Maclaren N. 1995. Insulin immunization of nonobese diabetic mice induces a protective insulitis characterized by diminished intraislet interferon- $\gamma$ transcription. J Clin Invest 95: 628-634.

Murgia C, Devirgiliis C, Mancini E, Donadel G, Zalewski P, Perozzi G. 2009. Diabetes-linked zinc transporter ZnT8 is a homodimeric protein expressed by distinct rodent endocrine cell types in the pancreas and other glands. Nutr Metab Cardiovasc Dis 19: 431-439.

Mziaut H, Trajkovski M, Kersting S, Ehninger A, Altkruger A, Lemaitre RP, Schmidt D, Saeger HD, Lee MS, Drechsel DN, et al. 2006. Synergy of glucose and growth hormone signalling in islet cells through ICA512 and STAT5. Nat Cell Biol 8: 435-445.

Nagamine K, Peterson P, Scott HS, Kudoh J, Minoshima S, Heino M, Krohn KJ, Lalioti MD, Mullis PE, Antonarakis SE, et al. 1997. Positional cloning of the APECED gene. Nat Genet 17: 393-398.

Naggert JK, Fricker LD, Varlamov O, Nishina PM, Rouille Y, Steiner DF, Carroll RJ, Paigen BJ, Leiter EH. 1995. Hyperproinsulinaemia in obese fat/fat mice associated with carboxypeptidase E mutation which reduces enzyme activity. Nature Genet 10: 135-142.

Nakagawa SH, Tager HS, Steiner DF. 2000. Mutational analysis of invariant valine B12 in insulin: Implications for receptor binding. Biochemistry (Mosc) 39: 15826-15835.

Nakagawa SH, Hua QX, Hu SQ, Jia W, Wang S, Katsoyannis PG, Weiss MA. 2006. Chiral mutagenesis of insulin. 
P. Arvan et al.

Contribution of the B20-B23 $\beta$-turn to activity and stability. J Biol Chem 281: 22386-22396.

Nakayama M, Abiru N, Moriyama H, Babaya N, Liu E, Miao D, Yu L, Wegmann DR, Hutton JC, Elliott JF, et al. 2005. Prime role for an insulin epitope in the development of type 1 diabetes in NOD mice. Nature 435: 220-223.

Nicolson TJ, Bellomo EA, Wijesekara N, Loder MK, Baldwin JM, Gyulkhandanyan AV, Koshkin V, Tarasov AI, Carzaniga R, Kronenberger K, et al. 2009. Insulin storage and glucose homeostasis in mice null for the granule zinc transporter ZnT8 and studies of the type 2 diabetes-associated variants. Diabetes 58: 2070-2083.

Nielsen LB, Vaziri-Sani F, Porksen S, Andersen ML, Svensson J, Bergholdt R, Pociot F, Hougaard P, de Beaufort C, Castano L, et al. 2011. Relationship between ZnT8Ab, the SLC30A8 gene and disease progression in children with newly diagnosed type 1 diabetes. Autoimmunity 44: 616623.

Novak EJ, Ortqvist E, Nord E, Edwall L, Hampe CS, Bekris L, Persson BE, Lernmark A. 2000. Stability of disease-associated antibody titers in pregnant women with type 1 diabetes with or without residual $\beta$-cell function. Diabetes Care 23: 1019-1021.

Ohneda K, Hooi E, German M. 2000. Regulation of insulin gene transcription. Sem Cell Dev Biol 11: 227-233.

Okun MM, Eskridge EM, Shields D. 1990. Truncations of a secretory protein define minimum lengths required for binding to signal recognition particle and translocation across the endoplasmic reticulum membrane. J Biol Chem 265: 7478-7484.

Orban T, Sosenko JM, Cuthbertson D, Krischer JP, Skyler JS, Jackson R, Yu L, Palmer JP, Schatz D, Eisenbarth G. 2009. Pancreatic islet autoantibodies as predictors of type 1 diabetes in the Diabetes Prevention Trial-Type 1. Diabetes Care 32: 2269-2274.

Orci L. 1985. The insulin factory: A tour of the plant surroundings and a visit to the assembly line. The Minkowski lecture 1973 revisited. Diabetologia 28: 528-546.

Orci L, Ravazzola M, Amherdt M, Madsen O, Vassalli JD. 1985. Direct identification of prohormone conversion site in insulin-secreting cells. Cell 42: 671-681.

Oslowski CM, Urano F. 2011. The binary switch that controls the life and death decisions of ER stressed $\beta$ cells. Curr Opin Cell Biol 23: 207-215.

Oyadomari S, Takeda K, Takiguchi M, Gotoh T, Matsumoto M, Wada I, Akira S, Araki E, Mori M. 2001. Nitric oxideinduced apoptosis in pancreatic $\beta$ cells is mediated by the endoplasmic reticulum stress pathway. Proc Natl Acad Sci 98: $10845-10850$.

Papa FR, Zhang C, Shokat K, Walter P. 2003. Bypassing a kinase activity with an ATP-competitive drug. Science 302: 1533-1537.

Peakman M, Stevens EJ, Lohmann T, Narendran P, Dromey J, Alexander A, Tomlinson AJ, Trucco M, Gorga JC, Chicz RM. 1999. Naturally processed and presented epitopes of the islet cell autoantigen IA-2 eluted from HLA-DR4. J Clin Invest 104: 1449-1457.

Permutt MA, Kakita K, Malinas P, Karl I, Bonner-Weir S, Weir G, Giddings SJ. 1984. An in vivo analysis of pancreatic protein and insulin biosynthesis in a rat model for non-insulin-dependent diabetes. J Clin Invest 73: 13441350.
Petersen AB, Smidt K, Magnusson NE, Moore F, Egefjord L, Rungby J. 2011. siRNA-mediated knock-down of ZnT3 and ZnT8 affects production and secretion of insulin and apoptosis in INS-1E cells. APMIS 119: 93-102.

Pietropaolo M, Eisenbarth GS. 2001. Autoantibodies in human diabetes. Curr Dir Autoimmun 4: 252-282.

Pietropaolo M, Castano L, Babu S, Buelow R, Kuo YL, Martin S, Martin A, Powers AC, Prochazka M, Naggert J, et al. 1993. Islet cell autoantigen $69 \mathrm{kD}$ (ICA69). Molecular cloning and characterization of a novel diabetes-associated autoantigen. J Clin Invest 92: 359-371.

Pietropaolo M, Yu S, Libman IM, Pietropaolo SL, Riley K, LaPorte RE, Drash AL, Mazumdar S, Trucco M, Becker DJ. 2005. Cytoplasmic islet cell antibodies remain valuable in defining risk of progression to type 1 diabetes in subjects with other islet autoantibodies. Pediatr Diabetes 6: 184-192.

Pietropaolo M, Barinas-Mitchell E, Kuller LH. 2007. The heterogeneity of diabetes. Unraveling a dispute: Is systemic inflammation related to islet autoimmunity? Diabetes 56: 1189-1197.

Pietropaolo M, Surhigh JM, Nelson PW, Eisenbarth GS. 2008. Primer: Immunity and autoimmunity. Diabetes 57: $2872-2882$.

Pilon M, Peng XR, Spence AM, Plasterk RH, Dosch HM. 2000. The diabetes autoantigen ICA69 and its Caenorhabditis elegans homologue, ric-19, are conserved regulators of neuroendocrine secretion. Mol Biol Cell 11: 3277-3288.

Poitout V, Stein R, Rhodes CJ. 2004. Insulin gene expression and biosynthesis. In International textbook of diabetes mellitus, 3rd ed., pp. 97-123. John Wiley \& Sons, Chichester.

Porte DJ. 1991. $\beta$-cells in type II diabetes mellitus. Diabetes 40: $166-180$.

Pound LD, Sarkar SA, Benninger RK, Wang Y, Suwanichkul A, Shadoan MK, Printz RL, Oeser JK, Lee CE, Piston DW, et al. 2009. Deletion of the mouse Slc30a8 gene encoding zinc transporter-8 results in impaired insulin secretion. Biochem J 421: 371-376.

Pound LD, Hang Y, Sarkar SA, Wang Y, Milam LA, Oeser JK, Printz RL, Lee CE, Stein R, Hutton JC, et al. 2010. The pancreatic islet $\beta$-cell-enriched transcription factor $\mathrm{Pdx}$ 1 regulates Slc30a8 gene transcription through an intronic enhancer. Biochem J 433: 95-105.

Qiao ZS, Min CY, Hua QX, Weiss MA, Feng YM. 2003. In vitro refolding of human proinsulin: Kinetic intermediates, putative disulfide-forming pathway, folding initiation site and potential role of C-peptide in folding process. J Biol Chem 278: 17800-17809.

Ramsey C, Winqvist O, Puhakka L, Halonen M, Moro A, Kampe O, Eskelin P, Pelto-Huikko M, Peltonen L. 2002. Aire deficient mice develop multiple features of APECED phenotype and show altered immune response. Hum Mol Genet 11: 397-409.

Rhodes CJ. 2004. Processing the insulin molecule. In Diabetes mellitus: A fundemental and clinical text (ed LeRoith D, Taylor SI, Olefsky JM), pp. 27-50. Lippincott-Raven, Philadelphia, PA.

Roep BO, Duinkerken G, Schreuder GM, Kolb H, de Vries RR, Martin S. 1996. HLA-associated inverse correlation between $\mathrm{T}$ cell and antibody responsiveness to islet 
autoantigen in recent-onset insulin-dependent diabetes mellitus. Eur J Immunol 26: 1285-1289.

Ron D, Walter P. 2007. Signal integration in the endoplasmic reticulum unfolded protein response. Nat Rev Mol Cell Biol 8: 519-529.

Ronkainen MS, Savola K, Knip M. 2004. Antibodies to GAD65 epitopes at diagnosis and over the first 10 years of clinical type 1 diabetes mellitus. Scand J Immunol 59: 334-340.

Ronkainen MS, Hoppu S, Korhonen S, Simell S, Veijola R, Ilonen J, Simell O, Knip M. 2006. Early epitope- and isotype-specific humoral immune responses to GAD65 in young children with genetic susceptibility to type 1 diabetes. Eur J Endocrinol 155: 633-642.

Saeki K, Zhu M, Kubosaki A, Xie J, Lan MS, Notkins AL. 2002. Targeted disruption of the protein tyrosine phosphatase-like molecule IA-2 results in alterations in glucose tolerance tests and insulin secretion. Diabetes 51: $1842-1850$.

Sando H, Borg J, Steiner DF. 1972. Studies on the secretion of newly synthesized proinsulin and insulin from isolated rat islets of Langerhans. J Clin Invest 51: 1476-1485.

Santamaria P, Utsugi T, Park BJ, Averill N, Kawazu S, Yoon JW. 1995. $\beta$-cell-cytotoxic CD8 ${ }^{+} \mathrm{T}$ cells from nonobese diabetic mice use highly homologous T cell receptor $\alpha$ chain CDR3 sequences. J Immunol 154: 2494-2503.

Schlosser M, Banga JP, Madec AM, Binder KA, Strebelow M, Rjasanowski I, Wassmuth R, Gilliam LK, Luo D, Hampe CS. 2005. Dynamic changes of GAD65 autoantibody epitope specificities in individuals at risk of developing type 1 diabetes. Diabetologia 48: 922-930.

Skowera A, Ellis RJ, Varela-Calvino R, Arif S, Huang GC, Van-Krinks C, Zaremba A, Rackham C, Allen JS, Tree TI, et al. 2008. CTLs are targeted to kill $\beta$ cells in patients with type 1 diabetes through recognition of a glucose-regulated preproinsulin epitope. J Clin Invest 118: $3390-3402$.

Smeekens SP, Montag AG, Thomas G, Albiges-Rizo C, Carroll R, Benig M, Phillips LA, Martin S, Ohagi S, Gardner P, et al. 1992. Proinsulin processing by the subtilisin-related proprotein convertases furin, PC2, and PC3. Proc Natl Acad Sci 89: 8822-8826.

Smidt K, Jessen N, Petersen AB, Larsen A, Magnusson N, Jeppesen JB, Stoltenberg M, Culvenor JG, Tsatsanis A, Brock B, et al. 2009. SLC30A3 responds to glucose- and zinc variations in $\beta$-cells and is critical for insulin production and in vivo glucose-metabolism during $\beta$-cell stress. PLoS ONE 4: e5684.

Solimena M, Folli F, Denis-Donini S, Comi GC, Pozza G, De Camilli P, Vicari AM. 1988. Autoantibodies to glutamic acid decarboxylase in a patient with stiff-man syndrome, epilepsy, and type I diabetes mellitus. $N$ Engl J Med 318: 1012-1020.

Solimena M, Dirkx RJ, Hermel JM, Pleasic-Williams S, Shapiro JA, Caron L, Rabin DU. 1996. ICA 512, an autoantigen of type I diabetes, is an intrinsic membrane protein of neurosecretory granules. EMBO J 15: 2102-2114.

Song A, Winer S, Tsui H, Sampson A, Pasceri P, Ellis J, Elliott JF, Dosch HM. 2003. Deviation of islet autoreactivity to cryptic epitopes protects NOD mice from diabetes. Eur J Immunol 33: 546-555.
Sorenson RL, Garry DG, Brelje TC. 1991. Structural and functional considerations of GABA in islets of Langerhans. $\beta$-cells and nerves. Diabetes 40: 1365-1374.

Stadinski BD, Delong T, Reisdorph N, Reisdorph R, Powell RL, Armstrong M, Piganelli JD, Barbour G, Bradley B, Crawford F, et al. 2010. Chromogranin A is an autoantigen in type 1 diabetes. Nat Immunol 11: 225-231.

Steck AK, Johnson K, Barriga KJ, Miao D, Yu L, Hutton JC, Eisenbarth GS, Rewers MJ. 2011. Age of islet autoantibody appearance and mean levels of insulin, but not GAD or IA-2 autoantibodies, predict age of diagnosis of type 1 diabetes: Diabetes autoimmunity study in the young. Diabetes Care 34: 1397-1399.

Stefan Y, Meda P, Neufeld M, Orci L. 1987. Stimulation of insulin secretion reveals heterogeneity of pancreatic B cells in vivo. J Clin Invest 80: 175-183.

Sumakovic M, Hegermann J, Luo L, Husson SJ, Schwarze K, Olendrowitz C, Schoofs L, Richmond J, Eimer S. 2009. UNC-108/RAB-2 and its effector RIC-19 are involved in dense core vesicle maturation in Caenorhabditis elegans. J Cell Biol 186: 897-914.

Tamaki M, Fujitani Y, Uchida T, Hirose T, Kawamori R, Watada H. 2009. Downregulation of ZnT8 expression in pancreatic $\beta$-cells of diabetic mice. Islets 1: 124-128.

Taupenot L, Harper KL, O'Connor DT. 2003. The chromogranin-secretogranin family. $N$ Engl J Med 348: 11341149.

Thebault-Baumont K, Dubois-Laforgue D, Krief P, Briand JP, Halbout P, Vallon-Geoffroy K, Morin J, Laloux V, Lehuen A, Carel JC, et al. 2003. Acceleration of type 1 diabetes mellitus in proinsulin 2-deficient NOD mice. J Clin Invest 111: 851-857.

Todd DJ, Lee AH, Glimcher LH. 2008. The endoplasmic reticulum stress response in immunity and autoimmunity. Nat Rev Immunol 8: 663-674.

Toma A, Haddouk S, Briand JP, Camoin L, Gahery H, Connan F, Dubois-Laforgue D, Caillat-Zucman S, Guillet JG, Carel JC, et al. 2005. Recognition of a subregion of human proinsulin by class I-restricted T cells in type $1 \mathrm{di}-$ abetic patients. Proc Natl Acad Sci 102: 10581-10586.

Toma A, Laika T, Haddouk S, Luce S, Briand JP, Camoin L, Connan F, Lambert M, Caillat-Zucman S, Carel JC, et al. 2009. Recognition of human proinsulin leader sequence by class I-restricted T-cells in HLA-A*0201 transgenic mice and in human type 1 diabetes. Diabetes 58: 394-402.

Torii S. 2009. Expression and function of IA-2 family proteins, unique neuroendocrine-specific protein-tyrosine phosphatases. Endocr J 56: 639-648.

Torii S, Saito N, Kawano A, Zhao S, Izumi T, Takeuchi T. 2005. Cytoplasmic transport signal is involved in phogrin targeting and localization to secretory granules. Traffic 6: 1213-1224.

Trajkovski M, Mziaut H, Schubert S, Kalaidzidis Y, Altkruger A, Solimena M. 2008. Regulation of insulin granule turnover in pancreatic $\beta$-cells by cleaved ICA512. J Biol Chem 283: 33719-33729.

Uchizono Y, Alarcon C, Wicksteed BL, Marsh BJ, Rhodes CJ. 2007. The balance between proinsulin biosynthesis and insulin secretion: Where can imbalance lead? Diabetes Obes Metab 9: 56-66. 
P. Arvan et al.

Vafiadis P, Ounissi-Benkalha H, Palumbo M, Grabs R, Rousseau M, Goodyer CG, Polychronakos C. 2001. Class III alleles of the variable number of tandem repeat insulin polymorphism associated with silencing of thymic insulin predispose to type 1 diabetes. J Clin Endocrinol Metab 86: $3705-3710$.

Verge CF, Gianani R, Kawasaki E, Yu L, Pietropaolo M, Jackson RA, Chase HP, Eisenbarth GS. 1996. Prediction of type I diabetes in first-degree relatives using a combination of insulin, GAD, and ICA512bdc/IA-2 autoantibodies. Diabetes 45: 926-933.

Vo YP, Hutton JC, Angleson JK. 2004. Recycling of the dense-core vesicle membrane protein phogrin in Min6 $\beta$-cells. Biochem Biophys Res Commun 324: 1004-1010.

Wang C, Mao R, Van de Casteele M, Pipeleers D, Ling Z. 2007. Glucagon-like peptide-1 stimulates GABA formation by pancreatic $\beta$-cells at the level of glutamate decarboxylase. Am J Physiol Endocrinol Metab 292: E1201-E1206.

Wasmeier C, Burgos PV, Trudeau T, Davidson HW, Hutton JC. 2005. An extended tyrosine-targeting motif for endocytosis and recycling of the dense-core vesicle membrane protein phogrin. Traffic 6: 474-487.

Welsh M, Nielsen DA, MacKrell AJ, Steiner DF. 1985. Control of insulin gene expression in pancreatic $\beta$-cells and in an insulin producing cell line, RIN-5F cells. II. Regulation of insulin mRNA stability. J Biol Chem 260: 13590 13594.

Wendt A, Birnir B, Buschard K, Gromada J, Salehi A, Sewing S, Rorsman P, Braun M. 2004. Glucose inhibition of glucagon secretion from rat $\alpha$-cells is mediated by GABA released from neighboring $\beta$-cells. Diabetes 53: 1038 1045.

Wenzlau JM, Juhl K, Yu L, Moua O, Sarkar SA, Gottlieb P, Rewers M, Eisenbarth GS, Jensen J, Davidson HW, et al. 2007. The cation efflux transporter ZnT8 (Slc30A8) is a major autoantigen in human type 1 diabetes. Proc Natl Acad Sci 104: 17040-17045.

Wenzlau JM, Hutton JC, Davidson HW. 2008a. New antigenic targets in type 1 diabetes. Curr Opin Endocrinol Diabetes Obes 15: 315-320.

Wenzlau JM, Liu Y, Yu L, Moua O, Fowler KT, Rangasamy S, Walters J, Eisenbarth GS, Davidson HW, Hutton JC. 2008b. A common nonsynonymous single nucleotide polymorphism in the SLC30A8 gene determines ZnT8 autoantibody specificity in type 1 diabetes. Diabetes 57: 2693-2697.

Wicksteed BL, Alarcón C, Briaud I, Dickson L, Lingohr MK, Rhodes CJ. 2003. Glucose-induced translational control of proinsulin biosynthesis is proportional to preproinsulin mRNA levels, but not regulated via a positive feedback of secreted insulin on in islet $\beta$-cells. J Biol Chem 278: 42080-42090.

Wicksteed BL, Uchizono Y, Alarcon C, McCuaig JF, Shalev A, Rhodes CJ. 2007. A cis-element in the $5^{\prime}$-untranslated region of the preproinsulin mRNA (ppIGE) is required for glucose regulation of proinsulin translation. Cell Metab 5: 221-227.

Wijesekara N, Chimienti F, Wheeler MB. 2009. Zinc, a regulator of islet function and glucose homeostasis. Diabetes Obes Metab 11: 202-214.

Wijesekara N, Dai FF, Hardy AB, Giglou PR, Bhattacharjee A, Koshkin V, Chimienti F, Gaisano HY, Rutter GA, Wheeler MB. 2010. $\beta$ cell-specific Znt8 deletion in mice causes marked defects in insulin processing, crystallisation and secretion. Diabetologia 53: 1656-1668.

Winer S, Gunaratnam L, Astsatourov I, Cheung RK, Kubiak V, Karges W, Hammond-McKibben D, Gaedigk R, Graziano D, Trucco M, et al. 2000. Peptide dose, MHC affinity, and target self-antigen expression are critical for effective immunotherapy of nonobese diabetic mouse prediabetes. J Immunol 165: 4086-4094.

Winer S, Tsui H, Lau A, Song A, Li X, Cheung RK, Sampson A, Afifiyan F, Elford A, Jackowski G, et al. 2003. Autoimmune islet destruction in spontaneous type 1 diabetes is not $\beta$-cell exclusive. Nat Med 9: 198-205.

Wong FS, Siew LK, Scott G, Thomas IJ, Chapman S, Viret C, Wen L. 2009. Activation of insulin-reactive CD8 T-cells for development of autoimmune diabetes. Diabetes 58: 1156-1164.

Yamamoto T, Yamato E, Tashiro F, Sato T, Noso S, Ikegami H, Tamura S, Yanagawa Y, Miyazaki JI. 2004. Development of autoimmune diabetes in glutamic acid decarboxylase 65 (GAD65) knockout NOD mice. Diabetologia 47: 221-224.

Yang Y, Hua QX, Liu J, Shimizu EH, Choquette MH, Mackin RB, Weiss MA. 2010. Solution structure of proinsulin: Connecting domain flexibility and prohormone processing. J Biol Chem 285: 7847-7851.

Zhu X, Orci L, Carroll R, Norrbom C, Ravazzola M, Steiner DF. 2002. Severe block in processing of proinsulin to insulin accompanied by elevation of des- 64,65 proinsulin intermediates in islets of mice lacking prohormone convertase 1/3. Proc Natl Acad Sci 99: 10299-10304.

Zimmet PZ, Tuomi T, Mackay IR, Rowley MJ, Knowles W, Cohen M, Lang DA. 1994. Latent autoimmune diabetes mellitus in adults (LADA): The role of antibodies to glutamic acid decarboxylase in diagnosis and prediction of insulin dependency. Diabet Med 11: 299-303.

Zoete V, Meuwly M, Karplus M. 2004. A comparison of the dynamic behavior of monomeric and dimeric insulin shows structural rearrangements in the active monomer. J Mol Biol 342: 913-929. 


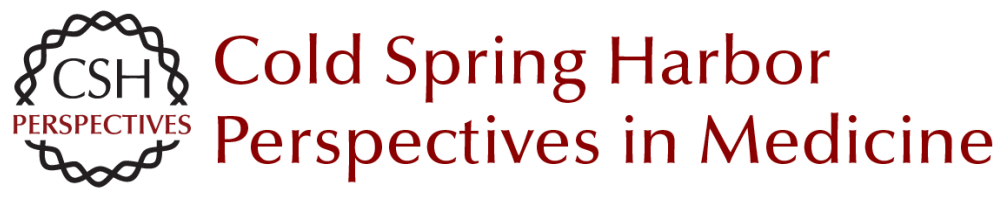

\section{Islet Autoantigens: Structure, Function, Localization, and Regulation}

Peter Arvan, Massimo Pietropaolo, David Ostrov and Christopher J. Rhodes

Cold Spring Harb Perspect Med 2012; doi: 10.1101/cshperspect.a007658 originally published online May 30, 2012

\section{Subject Collection Type I Diabetes}

The Pathogenesis and Natural History of Type 1 Diabetes

Mark A. Atkinson

Do MHCII-Presented Neoantigens Drive Type 1

Diabetes and Other Autoimmune Diseases?

Philippa Marrack and John W. Kappler

Clinical Immunologic Interventions for the

Treatment of Type 1 Diabetes

Lucienne Chatenoud, Katharina Warncke and

Anette-G. Ziegler

Update on Islet Transplantation

Michael McCall and A.M. James Shapiro

Immunologic and Metabolic Biomarkers of $\beta$-Cell

Destruction in the Diagnosis of Type 1 Diabetes Jasmin Lebastchi and Kevan C. Herold

Advancing Animal Models of Human Type 1

Diabetes by Engraftment of Functional Human

Tissues in Immunodeficient Mice

Michael A. Brehm, Alvin C. Powers, Leonard D.

Shultz, et al.

Breakdown in Peripheral Tolerance in Type 1

Diabetes in Mice and Humans

Lukas T. Jeker, Hélène Bour-Jordan and Jeffrey $A$. Bluestone

Antigen-Specific Therapeutic Approaches in Type 1 Diabetes

Xavier Clemente-Casares, Sue Tsai, Carol Huang, et al.
Humoral Autoimmunity in Type 1 Diabetes:

Prediction, Significance, and Detection of Distinct

Disease Subtypes

Massimo Pietropaolo, Roberto Towns and George S. Eisenbarth

Endoplasmic Reticulum Stress, Pancreatic $\beta$-Cell

Degeneration, and Diabetes

Feroz R. Papa

Islet Autoantigens: Structure, Function,

Localization, and Regulation

Peter Arvan, Massimo Pietropaolo, David Ostrov, et al.

Environmental Triggers of Type 1 Diabetes Mikael Knip and Olli Simell

Generating $\beta$ Cells from Stem Cells--The Story So

Far Matthias Hebrok

Antigen Targets of Type 1 Diabetes Autoimmunity Bart O. Roep and Mark Peakman

Connecting Type 1 and Type 2 Diabetes through Innate Immunity Justin I. Odegaard and Ajay Chawla

The Hygiene Hypothesis: An Explanation for the Increased Frequency of Insulin-Dependent Diabetes Jean-François Bach and Lucienne Chatenoud

For additional articles in this collection, see http://perspectivesinmedicine.cshlp.org/cgi/collection/ 